
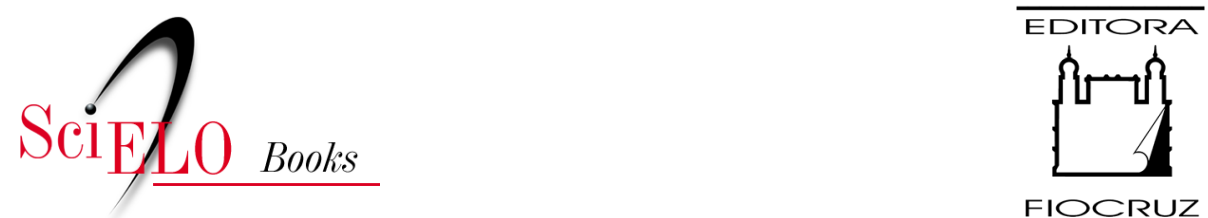

FIOCRUZ

\title{
3. Do Instituto Vacínico municipal ao Instituto Vacinogênico federal descentralização versus centralização
}

\author{
Tania Maria Fernandes
}

\section{SciELO Books / SciELO Livros / SciELO Libros}

FERNANDES, T.M. Do Instituto Vacínico municipal ao Instituto

Vacinogênico federal: descentralização versus centralização. In: Vacina Antivariólica: ciência, técnica e o poder dos homens, 1808-1920 [online]. 2nd ed. rev. Rio de Janeiro: Editora FIOCRUZ, 2010, pp. 65107. ISBN: 978-65-5708-095-5. https://doi.org/10.7476/9786557080955.0004.

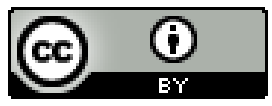

All the contents of this work, except where otherwise noted, is licensed under a Creative Commons Attribution 4.0 International license.

Todo o conteúdo deste trabalho, exceto quando houver ressalva, é publicado sob a licença Creative Commons Atribição 4.0.

Todo el contenido de esta obra, excepto donde se indique lo contrario, está bajo licencia de la licencia Creative Commons Reconocimento 4.0. 


\section{Do Instituto Vacínico Municipal ao Instituto Vacinogênico Federal: descentralização versus centralização}

O período que abrange as duas últimas décadas do Império até 1902 corresponde ao momento de atuação mais marcante de Pedro Affonso diante dos serviços de saúde, apoiado pelo conselheiro e médico Nuno de Andrade, diretor da Saúde Pública Federal. Os dois desempenharam o papel de autoridades máximas da saúde pública até a entrada em cena de Oswaldo Cruz e da consolidação da medicina experimental no país. ${ }^{1}$ Pedro Afonso, além de criar o Instituto Vacínico em 1894, organizou, em 1900, o Instituto Soroterápico Federal, mais tarde denominado Instituto Oswaldo Cruz, que ficou sob sua direção até 1902.

Apesar de o uso da vacina antivariólica animal ter sido consolidado durante o regime republicano, esse não foi um marco determinante para a sua institucionalização no Brasil. O apoio político adquirido por Pedro Affonso durante o governo imperial foi fundamental para a manutenção desse processo, que se manteve ao longo da Primeira República. A sustentação de Pedro Affonso na direção do Instituto Vacínico Municipal, até o início dos anos 20 do século XX, simboliza a correlação de forças políticas típica das três primeiras décadas da República, com a presença marcante de personagens herdados do governo imperial. Sua inserção como membro da elite imperial e a permanência desta no poder, observada após a 
proclamação da República, facilitaram suas articulações políticas e a conseqüente manutenção de seu trabalho.

A manutenção da elite política imperial no poder não exprimia, no entanto, um clima de estagnação. Pelo contrário, os anos que se sucederam à proclamação da República foram, principalmente para o Rio de Janeiro, capital do país, de intensa turbulência política e social, o que já se anunciava nos últimos anos do Império. Pode-se destacar um forte aumento demográfico, provocando um inchamento da cidade e contribuindo para novos surtos epidêmicos que marcaram sua história, como a ocorrência, em 1891, de um dos mais fortes surtos de varíola e febre amarela descritos até então. A situação sanitária refletia o caos com que se deparava a cidade, principalmente diante do aumento do custo de vida e da desvalorização da moeda no início da primeira década republicana.

O governo Campos Sales (1898-1902) conseguiu estabilizar a economia, impondo uma relativa calma ao cenário político, ideando a política dos governadores. Para ele, a única saída seria inverter as relações políticas e ter o governo federal com sustentação nas oligarquias estaduais (Viotti da Costa, 1979; Cardoso, 1977; Melo Franco, 1968). Nesse mesmo período, no entanto, foi criada a Diretoria Geral de Saúde Pública, visando à centralização dos serviços de higiene, apesar da proposta política mais geral de fortalecimento do poder local, o que inviabilizaria as medidas centralistas.

O conselheiro Rodrigues Alves assumiu, em 1902, a Presidência da República, preocupado com a higiene e o saneamento. Incumbiu o prefeito Pereira Passos e o cientista Oswaldo Cruz² da transformação da capital, de seu embelezamento e modernização, com base nos preceitos higienistas inovadores na época. Nesse período, verificou-se no Brasil a consolidação da medicina com base no método experimental, marcada sobretudo pela criação de institutos de pesquisa e produção de imunoterápicos, como, por exemplo, o Instituto Soroterápico Federal, na capital, e o Instituto Butantã, em São Paulo. ${ }^{3}$

Os sucessores de Rodrigues Alves, até a década de 1920, foram indicados e eleitos seguindo a mesma aliança alicerçada na política dos governadores. Até a Primeira Guerra Mundial, a política oligárquica manteve sua sustentação socioeconômica, abalada pelas alterações no comércio internacional, iniciando um processo de organização regional sustentado, sobretudo, na industrialização e formação de núcleos urbanos com outras lógicas de poder local. A eleição de 1919, que levou 
Epitácio Pessoa ao governo federal, demonstrou essa mudança e a desarticulação da política encaminhada pelos grandes estados, fortificando o discurso nacionalista.

Durante os primeiros vinte anos do século XX nesse contexto de poder oligárquico, discussões cruciais envolveram políticos e médicos em torno de propostas de centralização e descentralização dos poderes públicos na área da saúde. Esse debate instaurou um conflito entre posições divergentes a respeito da saúde pública, envolvendo em particular a vacina antivariólica.

Diante dessa polêmica sobre os rumos que a saúde pública deveria adotar, verificou-se uma tendência à mudança, que se concretizou com a criação do Departamento Nacional de Saúde Pública em 1920 e que implicou a exclusão da proposta de instituição sustentada por Pedro Affonso até aquele momento.

\section{As Primeiras Negociações de Pedro Affonso: seu instituto como meta}

A formalização da responsabilidade de Pedro Affonso, quanto à vacinação antivariólica no Distrito Federal, iniciou-se antes do surgimento do Instituto Vacínico, em consonância com os serviços sanitários da capital. Vários órgãos foram criados no primeiro decênio republicano, refletindo conjunturalmente as propostas de centralização e descentralização que se alternavam. A responsabilidade pelos serviços de saúde era transferida da União para os governos municipais e estaduais, e destes para o governo central.

No Distrito Federal, a situação administrativa era muito confusa, uma vez que este, segundo a própria Diretoria Geral de Higiene e Assistência Pública, assumia "um tríplice papel de município, estado e território federal, propiciando a criação de produtos administrativos heterogêneos, confusos e anômalos, principalmente por parte da municipalidade e da União" (Diretoria Geral de Assistência e Saúde Pública, 1909).

Uma das primeiras tentativas de estruturação dos serviços de saúde do Distrito Federal, nesse período, para distinguir as competências do município e da União, ocorreu em 1889. No âmbito do município, foi criado o Conselho de Intendência Municipal, com a atribuição de zelar pela saúde da população da cidade, ao passo que um decreto federal 
regularizava, na Inspetoria Geral de Higiene, o serviço de polícia sanitária na capital, permitindo a adoção de medidas sanitárias em todos os estados em caso de epidemias.

No ano seguinte, o governo federal reorganizou o serviço sanitário terrestre da República, ampliando as competências da Inspetoria Geral de Higiene em todo o Brasil e constituindo o Conselho de Saúde Pública. Foram criadas inspetorias de higiene nos estados, sob a coordenação da Inspetoria Geral, por meio de inspetores e delegados locais. A criação das inspetorias regionais era uma proposta de atuação provisória, pois estas serviram de base para a estruturação das organizações locais, devendo ser extintas ou transferidas para os estados e municípios. Dessa forma, o nível local de serviços de saúde pública estaria moldado pela orientação federal. A partir de 1891, essas inspetorias iniciaram seu processo de extinção ou transferência dos serviços para as administrações locais.

Nesse contexto de tentativas de equilibrar as propostas de centralização e descentralização, prevaleceu o controle federal sobre as organizações locais de saúde, e a proposta elaborada por Pedro Affonso para criar um Instituto Vacínico não encontrou dificuldades de viabilização. Como já vimos, ele havia elaborado várias propostas semelhantes desde 1888.

A legislação de 1890, que criou as inspetorias locais, estabeleceu que Pedro Affonso seria responsável pela produção da vacina, cedendo vitelos vacinados à Inspetoria Geral de Higiene para que esta aplicasse a vacina diretamente do animal, recebendo para isso subvenções do governo federal.

Em 1891, essas subvenções foram substituídas por um contrato com o governo da União para o fornecimento de vacina ao Distrito Federal por intermédio da Inspetoria Geral de Saúde Pública. A partir desse contrato, as vacinas chegariam à Inspetoria em tubos com linfa glicerinada, incorporando uma importante descoberta para sua conservação e purificação. Com a utilização da glicerina adicionada à linfa vacínica, não era mais preciso aplicar a vacina diretamente do vitelo ao homem. Além disso, a vacina poderia ser transportada com maior segurança quanto à manutenção do poder imunizante.

Com a criação da prefeitura do Distrito Federal, em 1892, os serviços de saúde pública da capital sofreram uma reestruturação. As legislações elaboradas com esse intuito, nas esferas tanto municipal como federal, no entanto, não se referiam aos serviços de higiene defensiva da capital. Mesmo sem respaldo legal, a prefeitura acabou assumindo a 
responsabilidade por esses serviços, que foram, posteriormente, solicitados pela União e para ela transferidos de forma definitiva em 1904.

Diante do fato de a municipalidade ter assumido, em 1892, os serviços de higiene da capital republicana, Pedro Affonso, para não perder a subvenção que vinha recebendo - garantia da sobrevivência da produção da vacina -, procurou imediatamente o governo municipal, ao qual cabia administrar os serviços de saúde da cidade.

No decorrer de 1894, enquanto Pedro Affonso buscava junto à prefeitura um acordo mais sólido para a fabricação da vacina no laboratório de sua propriedade, o senador Abdon Milanez apresentou projeto de criação de um instituto para a fabricação da vacina antivariólica, vinculado ao governo federal. O projeto, apresentado ao Senado em 19 de julho, foi impugnado sob a justificativa de inconstitucionalidade. $\mathrm{O}$ autor defendeu-o com base na legislação municipal, com a interpretação de que caberia ao município somente o serviço de vacinação, ficando a União responsável pela produção da vacina antivariólica (Anais da Câmara dos Deputados, sessão de 26/7/1894).

Em virtude da impugnação do projeto, o senador solicitou que a proposta fosse apreciada pela Comissão de Saúde Pública do Senado. Mais uma vez, o projeto recebeu parecer negativo, com base em sua possível inconstitucionalidade e em outros argumentos, voltados principalmente para o fato de já estar em discussão, no âmbito do município, a organização de um Instituto Vacínico que não acarretaria gastos aos cofres da União. Esse argumento foi utilizado pelos partidários de Pedro Affonso, que desejavam implementar seu projeto. ${ }^{4}$

A principal crítica do senador Abdon Milanez baseava-se no fato de que esse Instituto Municipal não se constituiria em instituição oficial. Dessa forma, segundo ele, o serviço de vacinação poderia ser desestruturado caso Pedro Affonso resolvesse rescindir o contrato, ficando o "Distrito Federal sem vacina depois de ter gasto centenas de contos de réis”. Em defesa de sua proposta, argumentava que a União não deveria economizar gastos, dada a dimensão do projeto. O senador comentou ainda, em seu discurso publicado nos Anais do Senado em 1894, que

se um particular dispõe de recursos para montar um Instituto Vacínico e dele tirar vantagens materiais, é lamentável que o país esteja em tais condições financeiras que não possa gastar quantias insignificantes para fundar também um instituto que tenha por fim garantir a vida de sua população. 
A temática centralização e descentralização teve destaque nesse debate, a exemplo da crítica do senador Rosa Jr. ao projeto centralista de Milanez. Afirmava ele, em discurso publicado nos Anais do Senado referente à sessão de 7 de agosto de 1894, que "o projeto ressente-se de mil vícios, entre os quais não pouco avulta o resultante do elemento centralizador, funesta herança das velhas instituições". Nesta mesma sessão, a votação do projeto foi adiada por falta de quórum, e a proposta não voltou mais a ser apresentada.

A derrota do senador Milanez fortaleceu Pedro Affonso, uma vez que o governo, perante a falta de consenso entre os médicos e da carência de recursos humanos capacitados, não conseguia formular uma proposta viável. Com essa vitória, Pedro Affonso conquistou apoio político decisivo. Em setembro do mesmo ano, o prefeito, por decreto municipal, foi autorizado a assinar o contrato que criava o Instituto Vacínico Municipal, instalado em um prédio à rua do Catete, 197, pertencente a Pedro Affonso.

\section{Instituto Vacínico Municipal: a vacina animal amplia seus horizontes}

O Instituto Vacínico Municipal, organizado por Pedro Affonso por intermédio de um contrato de manutenção com a prefeitura do Distrito Federal, foi uma iniciativa pioneira, de fundamental importância para a difusão da vacina animal em outros estados a partir da experiência da capital republicana.

Apesar de sua manutenção ter-se vinculado a um contrato de subvenção, esse instituto não se caracterizava, propriamente, como um órgão filantrópico. Estabelecia, assim, uma relação com o governo bastante típica daquela conjuntura, em que iniciativas particulares no âmbito da medicina eram reforçadas pelo Estado, como no caso da Policlínica do Rio de Janeiro e de algumas clínicas no interior da Faculdade de Medicina. O próprio Pedro Affonso definiu essa relação afirmando que o Instituto Vacínico Municipal "foi criado por nossa iniciativa particular e nos pertence. Não é um estabelecimento Oficial nem de caridade” (Instituto Vacínico Municipal. Relatório dos Trabalhos, 1915: 6).

O contrato inicialmente estabelecido para o funcionamento do Instituto Vacínico se constituía por uma proposta de trabalho cujos pontos 
básicos foram sustentados ao longo do período de manutenção do Instituto. O decreto legislativo, que autorizava o prefeito a aceitar a proposta formulada por Pedro Affonso, definia que o Instituto seria considerado uma repartição municipal, funcionando sob inspeção da Diretoria de Higiene, isenta do pagamento de impostos e dos gastos com gás, água e objetos de escritório. Para Pedro Affonso, segundo a citação anterior, a 'repartição municipal', conforme descrita no contrato, certamente não simbolizava uma instituição oficial. Ainda de acordo com esse contrato, os funcionários do corpo técnico seriam nomeados pelo prefeito por intermédio da Diretoria de Higiene.

Apesar de o contrato ter sido estabelecido no âmbito municipal, era intenção de Pedro Affonso divulgar a vacina em outros estados. Quanto a essa proposição, afirmava ele:

Desde 1887, época em que introduzi a vacina animal entre nós, até 1895 , forneci gratuitamente ao público e a todos os estados da União a vacina preparada a expensas minhas nos institutos por mim criados e mantidos. Esforcei-me por obter que todos os estados montassem Institutos Vacínicos seus, enviei para isso emissários que percorreram o nosso país do Norte ao Sul, praticando a vacinação e ensinando a fazer a cultura da vacina animal, para generalizá-la (Franco, 1917: 59)

De fato, em diversos momentos, Pedro Affonso enviou comissários - entre eles Dodsworth, Paulino Werneck, Arthur da S. Pereira e S. Thiago - aos estados para transmitir conhecimentos sobre a vacinação. Como parte dessa estratégia, criaram-se institutos vacínicos em vários estados, como em São Paulo, Minas Gerais, Rio Grande do Sul, Mato Grosso, Bahia e Pernambuco (Franco, 1917).

O estado do Ceará, constantemente assolado pela seca e conseqüentes surtos de varíola, teve o farmacêutico Rodolpho Teóphilo como responsável pela difusão da vacina animal, vinda do Instituto Vacinogênico de São Paulo, tendo criado também um instituto vacinogênico para a difusão da vacina. Era comum vê-lo puxando uma vaca "pelo cabresto entre a população miserável e usando o material dessa fonte diretamente para o braço humano" (Anais da Faculdade Nacional de Farmácia, 19521954). A Figura 4 ilustra uma cena da peregrinação de Rodolpho Teóphilo pelo sertão cearense. 
Figura 4 - Cena de vacinação no Ceará. Rodolpho Teóphilo e populares, tendo ao fundo um vitelo para a extração e inoculação direta da vacina

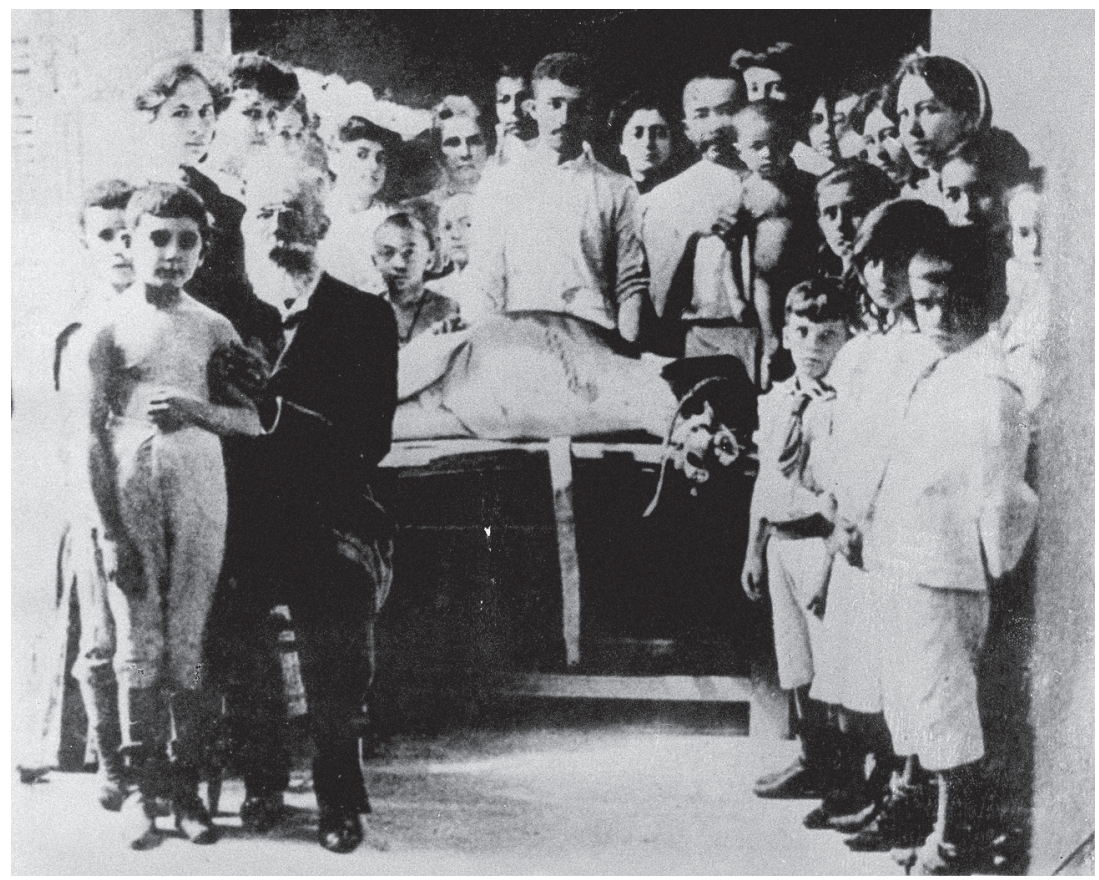

Fonte: Acervo da Casa de Oswaldo Cruz/Fiocruz.

A fim de viabilizar a difusão da vacina em todo o país, Pedro Affonso procurou estabelecer um convênio com o governo federal paralelamente ao já firmado com a municipalidade. Para isso, em 1897, o Instituto passou a receber subvenções e indenizações do governo federal ou dos estados pela vacina que fornecesse, devendo empregar essa verba na manutenção do pessoal do Instituto, no pagamento de trabalho extra ou na contratação de novos comissários vacinadores. Essa legislação modificava a relação empregatícia determinada inicialmente para a instituição, que passaria a ser sustentada por verbas extramunicipais, remunerando diretamente alguns funcionários.

Ao longo do período estabelecido para vigorar o primeiro contrato, ocorreram algumas alterações de caráter administrativo no Instituto. Em 1897, definiu-se a estrutura de pessoal, ficando o órgão composto por um diretor, cinco comissários vacinadores e quatro ajudantes, estes últimos, estudantes de medicina. Além disso, entre os comissários 
vacinadores, seria nomeado um vice-diretor para substituir o diretor em seus impedimentos.

Do ponto de vista da organização sanitária federal, desde 1892, quando foi criada a Inspetoria Geral de Higiene, vários órgãos surgiram e, sucessivamente, foram sendo substituídos, até que em 1897 constituiuse a Diretoria Geral de Saúde Pública, que permaneceu como órgão central da saúde pública até 1920.

É importante ressaltar que a unificação presente nessa reestruturação dos serviços, com a criação da Diretoria, não significava centralização de poderes públicos. Apenas estavam se concentrando em um mesmo órgão ações dispersas em outras pequenas estruturas. Era uma organização de âmbito administrativo, pois não existia ainda um regulamento dos serviços, com uma normatização que refletisse a centralização do poder.

Após várias tentativas, parecia que a Diretoria Geral tinha conseguido conservar certa estabilidade, pelo menos no que dizia respeito ao nome da instituição, que se manteve até o início da década de 20 do século XX, tendo passado, no entanto, por diversas estruturações ao longo do período.

A duração do contrato original do Instituto Vacínico com a prefeitura era de dez anos, período que findaria em 1904. Por coincidência, esse seria o momento de profundas discussões sobre a reestruturação dos serviços de saúde da capital republicana, quando a permanência do Instituto Vacínico fora da estrutura do Instituto Soroterápico Federal constituiu alvo de polêmicas.

\section{Ascensão de Oswaldo Cruz na Saúde Pública: ameaça ao barão de Pedro Affonso}

Ao assumir a Presidência da República, Rodrigues Alves nomeou Oswaldo Cruz para a Diretoria Geral de Saúde Pública. Recentemente, este substituíra o barão de Pedro Affonso na direção do Instituto Soroterápico Federal após intensas polêmicas internas. Ao assumir os serviços de higiene, em março de 1903, Oswaldo Cruz buscou reestruturá-los tendo como princípio básico a sua centralização, procurando alterar a fragmentação existente até então. Sua proposta, apresentada no Congresso Nacional em junho do mesmo ano pelo deputado Mello Mattos, ${ }^{5}$ incluía a incorporação dos serviços de higiene da capital federal, assumidos desde 
1892 pelo governo municipal. Além disso, pretendia controlar a produção da vacina antivariólica, incluindo-a na pauta de responsabilidades do Instituto Soroterápico Federal. Tal idéia, evidentemente, gerou atrito com Pedro Affonso, com quem sua relação já não era amistosa desde os tempos do Instituto Soroterápico. ${ }^{6}$

O Projeto de Reestruturação dos Serviços de Saúde na capital da República gerou um processo intenso de discussão e foi condenado ou defendido por diversos grupos no Congresso Nacional, na imprensa, nos meios acadêmicos, assim como na Academia Nacional de Medicina e nos congressos médicos. O Apostolado Positivista e alguns positivistas não vinculados a ele caracterizaram a proposta como 'Código de Torturas', fruto de 'despotismo sanitário' (Porto, 1985). ${ }^{7}$

Um dos pontos polêmicos insistentemente referido foi o da centralização. Seus detratores utilizavam como argumento central o princípio federalista da autonomia estadual. Na Câmara dos Deputados, entre os representantes dessa posição, encontrava-se o deputado Teixeira Brandão, membro da Comissão de Saúde da Câmara. ${ }^{8}$

É nesse contexto, de centralização versus descentralização, que localizamos o debate a respeito da vacina antivariólica. Embora não reivindicasse explicitamente a produção desta, o Projeto Mello Mattos, ao procurar centralizar a produção de todos os imunoterápicos no Instituto Soroterápico Federal, estaria, conseqüentemente, deslocando-a do âmbito do Instituto Vacínico Municipal.

Diante da intensa polêmica gerada pelas propostas do projeto e com a intenção de abordar as questões que se vinculavam à vacina antivariólica, Pedro Affonso solicitou à Comissão de Saúde da Câmara que lhe permitisse um pronunciamento, o que ocorreu em 30 de julho de 1903. Criticou a proposta de ampliação das responsabilidades do Instituto Soroterápico, baseando seu parecer no fato de "não existir no mundo (até então) um Instituto com tão vasto programa”, ressaltando ainda que "seria um perigo para a saúde pública" fabricar a vacina antivariólica no mesmo local onde se produziam outros imunoterápicos, como antipestoso e anticarbunculoso. A questão apontada por ele em seu discurso na Câmara dos Deputados em 30/7/1903, em relação à fabricação de vários produtos em um mesmo local, teria como base a afirmativa de que o vitelo preparado para a vacina do carbúnculo, estando próximo ao vitelo da vacina contra a varíola, poderá, por meio de moscas, transmitir a este o carbúnculo com grave perigo para as pessoas 
vacinadas contra a varíola, porque arriscam-se a adquirir o gérmen do 'carbúnculo'. (O Paiz, 31/7/1903)

Outra questão apontada por Pedro Affonso dizia respeito aos gastos públicos. Ele defendia a economia que representava para os cofres do Estado a manutenção de seu Instituto ao invés de se organizar um novo serviço para substituir o existente. Sobre esse assunto, interrogava: "para que montar em Manguinhos um novo instituto de vacina antivariólica dando à população receios fundados de inoculações perigosas, distraindo de trabalhos necessários pessoal numeroso, e desperdiçando dinheiros públicos que poderiam ter melhor aplicação?” (Recortes de jornal. Acervo da Casa de Oswaldo Cruz).

Coerentemente com sua proposta, defendia a municipalização do serviço de vacinação, sem, contudo, referir-se à descentralização dos serviços de saúde pública como um todo, que, para ser igualmente coerente, deveria apoiar. Talvez, para Pedro Affonso, fosse mais conveniente não explicitar determinadas idéias, para não correr o risco de se contrapor a algum aliado.

Por intermédio da imprensa, o deputado Mello Mattos, autor do projeto, criticou o pronunciamento de Pedro Affonso na Câmara, contestando as justificativas técnicas indicadas por este quanto ao perigo de fabricar diferentes vacinas em um mesmo laboratório. Quanto à manutenção do Instituto Vacínico, afirmava que "o preparo da vacina antivariólica em Manguinhos ou em outro estabelecimento do Rio de Janeiro traria graves perigos não para a saúde pública”, como sustentava Pedro Affonso, "mas para a prorrogação do contrato de monopólio do Instituto Vacinogênico ${ }^{9}$ (Jornal do Commercio, 15/12/1903).

Pedro Affonso respondeu aos ataques de Mello Mattos, porém negou-se a responder às questões de 'ciência', justificando que o deputado estava sendo movido por um “ódio pessoal, injusto e ingrato” a ele. Quanto ao termo 'monopólio', utilizado em referência ao contrato do Instituto com a prefeitura, o barão contrapôs ressaltando a participação e a responsabilidade do Instituto do Rio de Janeiro na criação de outros órgãos de cultura e prática da vacina animal nos diversos estados (Jornal do Commercio, 16/12/1903).

Os argumentos de defesa de Pedro Affonso sobre as questões técnicas refutadas por Mello Mattos eram, na realidade, bastante frágeis, mesmo diante do conhecimento científico da época. Eram problemas de solução física, superáveis por meio de métodos de assepsia e cuidados de 
isolamento ambiental, já conhecidos naquele momento. Apesar disso, o prestígio de Pedro Affonso continuou inabalável. A delicada posição do governo, quanto às polêmicas travadas diante do projeto de estruturação da higiene, e o apoio que o próprio Pedro Affonso conquistara junto aos políticos e médicos permitiram a manutenção do Instituto Vacínico sob sua direção.

Na Câmara, o deputado Germano Hasslocher, membro da Comissão de Saúde Pública, foi o único, além de Mello Mattos, a se pronunciar contra o trabalho do Instituto Vacínico Municipal e de Pedro Affonso após o comparecimento deste à Comissão. Com base nas idéias positivistas contra os imunoterápicos, criticou os institutos em geral, referindo-se a eles, pejorativamente, como 'fábricas de caldos'. Censurou também os contratos de Pedro Affonso com a prefeitura, afirmando que esse médico obtinha lucros financeiros graças ao Instituto.

Pedro Affonso conquistou apoio para a manutenção de seu Instituto entre os parlamentares, entre eles os deputados Corrêa Dutra e Brício Filho, ambos membros da Comissão de Saúde. Este último apresentou duas emendas ao projeto, que foram aceitas como proposta para o texto final. A primeira defendia a prerrogativa do Instituto Vacínico Municipal de fornecer vacina aos estados, e a segunda excluía qualquer possibilidade de o Instituto Soroterápico Federal produzir a vacina (Anais da Câmara dos Deputados, sessão de 5/12/1903).

Como conseqüência dessas discussões, a legislação que reestruturou os serviços sanitários, datada de 5 de janeiro de 1904, impedia o Instituto Soroterápico Federal de incluir em sua produção a vacina antivariólica. ${ }^{10}$ Dessa forma, o Poder Legislativo autorizou o prefeito a prorrogar por sete anos o contrato assinado em 1894 entre a prefeitura e o Instituto Vacínico Municipal.

A prorrogação do contrato, nesse momento, resultou do processo político encaminhado por Pedro Affonso e que, em busca de apoio, incluía não só parlamentares, como a classe médica e a opinião pública. Para dar maior visibilidade a seu trabalho, Pedro Affonso assumia, como estratégia, divulgar - por meio da grande imprensa e das publicações especializadas em medicina e saúde pública -, consultar profissionais da área e convidar políticos e personalidades para visitas às instalações do Instituto. O próprio presidente Rodrigues Alves, com representantes do setor público, da classe médica e da elite política, visitou o Instituto Vacínico, o que reverteu em grande propaganda para a instituição. 
O médico higienista Arthur Neiva, posteriormente, colocaria essa 'vitória' em um patamar de relações pessoais e de 'natureza sentimental', pois o Instituto foi criado na gestão de Bento Cruz - pai de Oswaldo Cruz - como diretor da Saúde Pública, contando com seu apoio (Neiva, 1917). ${ }^{11}$

Concordando em parte com Neiva, acrescentamos que o reverso da moeda também existe, pois certamente a amizade entre Pedro Affonso e Bento Cruz foi decisiva para que Oswaldo Cruz desse seus primeiros passos em Manguinhos, ao lado do próprio Pedro Affonso, com quem teria, como já visto, sérias desavenças (Fernandes, 1989).

A discussão gerada em torno da reestruturação de 1904 pode ser considerada um marco decisivo para o Instituto Vacínico Municipal. Apesar da vitória setorial obtida por Pedro Affonso, firmou-se a partir desse momento uma tendência inovadora e contrária aos fundamentos que mantinham o Instituto com o perfil que Pedro Affonso lhe imprimira. Oswaldo Cruz transformou-se em ameaça para Pedro Affonso nesse novo contexto, não só com relação à atribuição dos dois institutos - Vacínico e Soroterápico - como também quanto à organização estatal dos serviços de saúde, que era vislumbrada de forma distinta pelos dois médicos. Para Pedro Affonso, a estruturação da saúde pública passaria pela participação da iniciativa particular, financiada pelo Estado, enquanto Oswaldo Cruz construía um aparato estatal centralizado.

Outra questão relevante nesse debate referia-se à obrigatoriedade da vacina antivariólica. O projeto de Mello Mattos propunha essa medida como a mais eficaz para o controle da varíola, reativando uma discussão que acompanhou a vacina desde os primórdios. Em geral, a contestação a essa medida envolvia duas questões distintas. Uma dizia respeito à eficácia da vacina, típica dos que se opunham à teoria microbiana. A outra tinha como base o caráter coercitivo e era suscitada pelos que defendiam o direito de liberdade individual diante dos problemas da saúde. Esta última envolvia uma grande carga de valores morais, denunciando a vacinação como um instrumento de violação da privacidade e da integridade individual, principalmente das mulheres. As charges a seguir (Figuras 5 a 9) apontam para tais questões. 
Figura 5 - Avenida (08/10/1904)

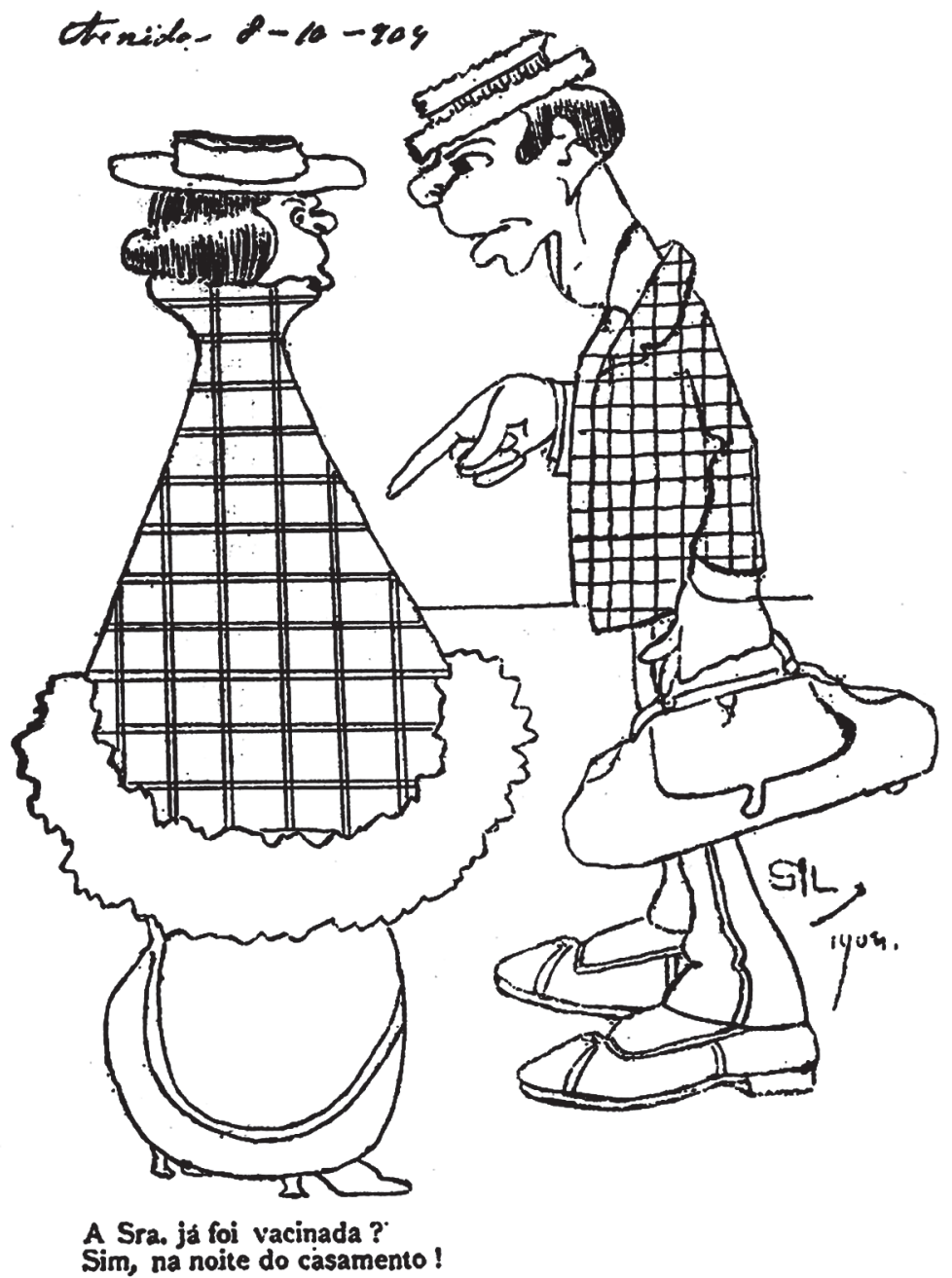

Fonte: Falcão (1971).

Entre os que se opunham à obrigatoriedade da vacina no Brasil, destacavam-se os positivistas, grupo mais radical de oposição à vacina, apesar das divergências existentes entre eles quanto à questão. Os nãofiliados ao Apostolado pronunciavam-se, em geral, de forma menos ortodoxa. ${ }^{12}$ 
Figura 6-A Vaccina obrigatoria

A VACCINA OBRIGATORIA

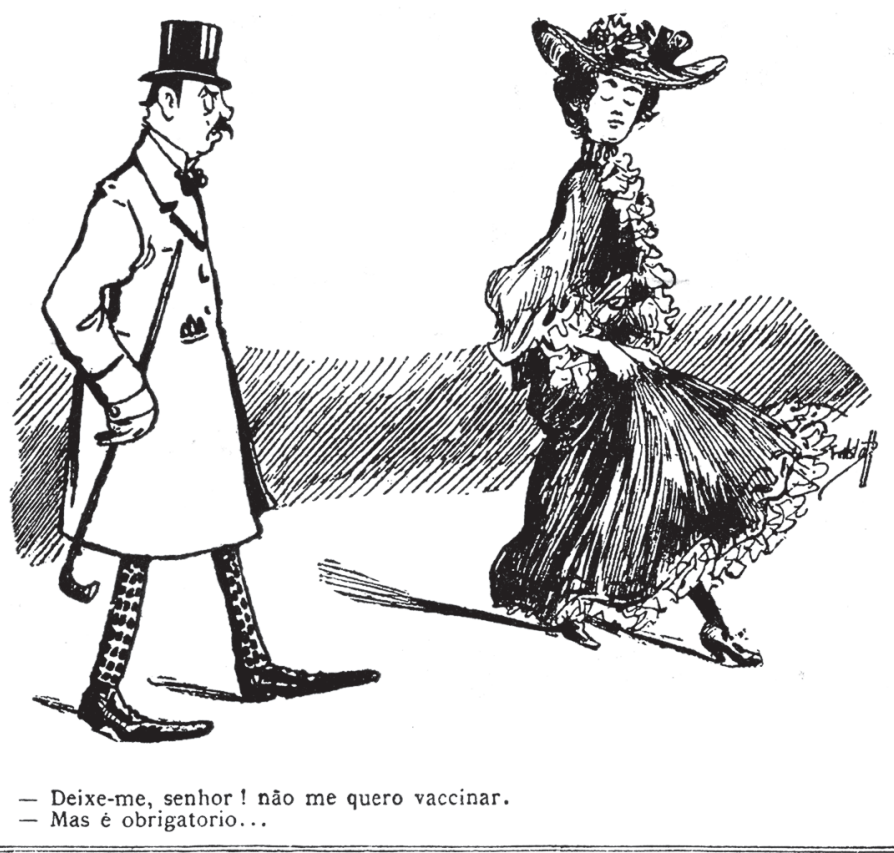

Fonte: Falcão (1971).

A discussão na Câmara quanto à obrigatoriedade foi bastante polêmica, sendo ressaltada por Barbosa Lima, contrário à vacinação obrigatória, a discordância entre os próprios médicos quanto à sua indicação. Entre os que apoiavam a vacina, destacavam-se Rodrigues Dória e Teixeira Brandão, sendo que Dória defendia enfaticamente o direito de o Estado impor a vacina, desde que fossem garantidos o rigor técnico do processo de fabricação e a gratuidade de seu fornecimento. Em várias charges publicadas na imprensa ilustram-se as discussões travadas na Câmara, principalmente as protagonizadas por Barbosa Lima (Figuras 10-11, mais adiante). 
Figura 7 - Tagarela (18/08/04)

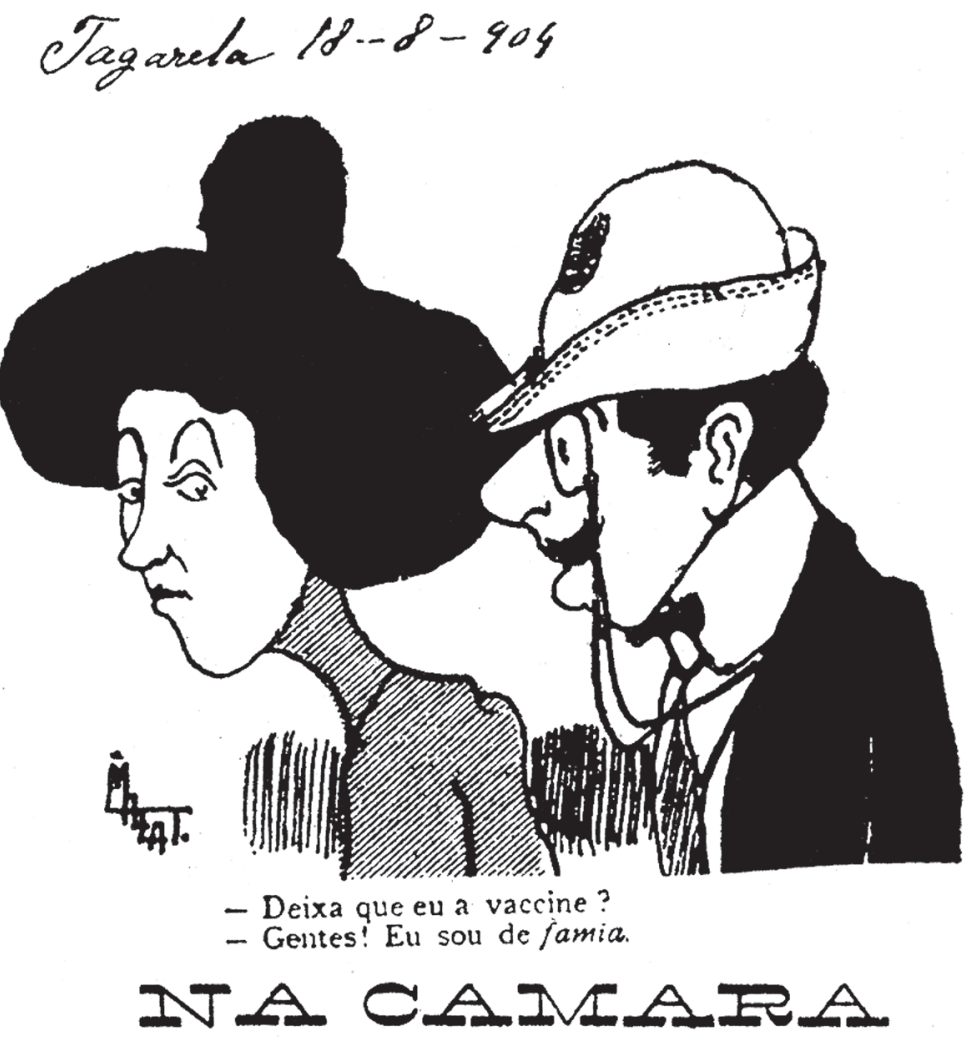

Fonte: Falcão (1971).

O barão de Pedro Affonso, em pronunciamento diante da Comissão de Saúde da Câmara, defende a obrigatoriedade da vacina como a 'salvação do povo', acrescentando que "isto se impõe ao patriotismo e à sabedoria do Congresso" (Correio da Manhã, 31/7/1903). Apesar de terse manifestado a favor, Pedro Affonso nunca abraçou essa causa com muita veemência. Esse debate, bastante polêmico, expressava pontos de vista e interesses, em algumas ocasiões, divergentes e, em outras, próximos, confundindo os adeptos e os opositores das posições em jogo.

A versão final do projeto, publicada em janeiro de 1904, excluiu a obrigatoriedade da vacina entre as medidas adotadas. A retirada da vacinação obrigatória foi qualificada posteriormente pelo deputado Correia Dutra, adepto da medida, como conseqüência de 'conchavos' ocorridos em última hora devido ao receio de que o projeto não fosse aprovado, 
uma vez que essa questão vinha acrescentando muita polêmica à discussão da proposta (Anais da Câmara dos Deputados, sessão de 26/08/1904). Na charge da Figura 12, mais adiante, retrata-se o possível descontentamento de alguns políticos e de Oswaldo Cruz.

Figura 8 - A vaccinação. Correio (1/10/1904)

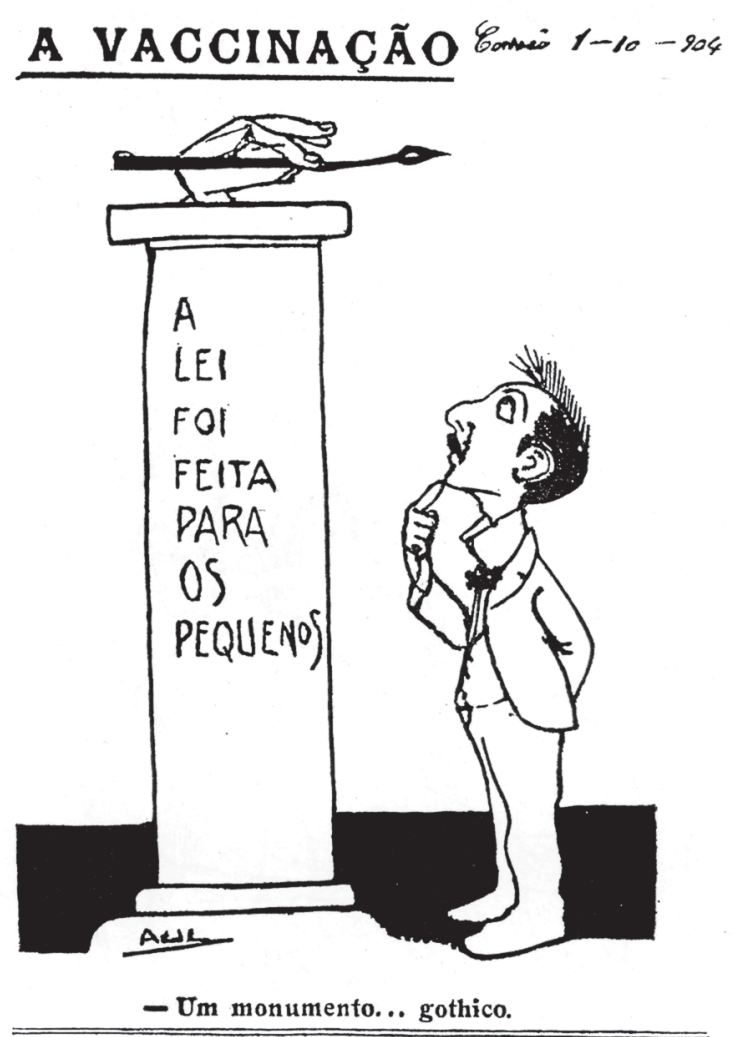

Fonte: Falcão (1971).

Na realidade, a proposição de Mello Mattos tinha como preocupação fundamental o controle da febre amarela, conforme observamos na mensagem de Oswaldo Cruz encaminhada ao ministro do Interior e que, claramente, serviu de base para a elaboração do projeto. Diante disso, a questão da vacina era uma preocupação secundária que não poderia prejudicar o andamento desse projeto e, portanto, poderia ser retirada momentaneamente, como estratégia de negociação política. 
No último Parecer das Comissões de Instrução e Saúde da Câmara, depois de suprimida a obrigatoriedade da vacinação, destacou-se a supressão da medida, indicando-se que, dessa forma, "atende-se mais particularmente ao direito e liberdade individual" (Anais da Câmara dos Deputados, sessão de 8/12/1903).

Figura 9 - O espeto obrigatório. A Avenida

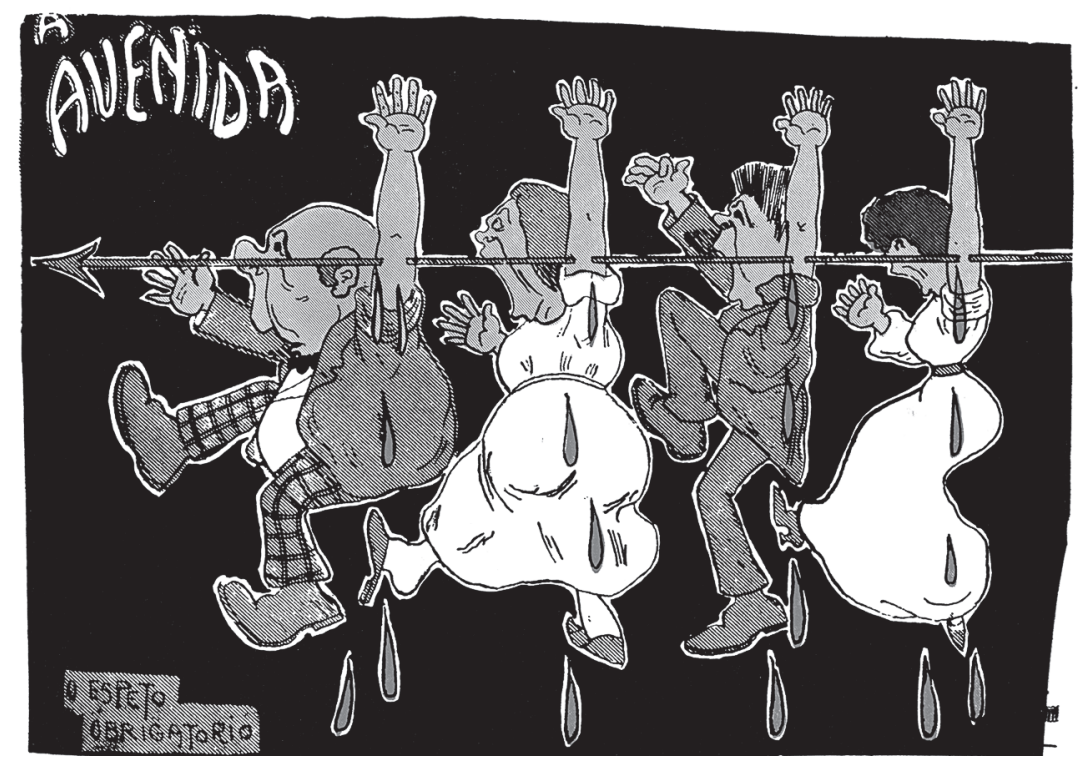

Fonte: Falcão (1971).

Enquanto o projeto tramitava na Câmara e no Senado, e mesmo após ter sido aprovado, outros fóruns de discussão manifestaram-se quanto às suas proposições. Entre eles, destaca-se a Academia Nacional de Medicina, cujos membros afirmavam ser consensual seu apoio à medida.

O periódico Brazil Médico concentrou uma série de publicações de artigos e reproduções de pareceres oficiais sobre a vacinação, acompanhando as discussões e se pronunciando em suas seções editoriais em favor do regulamento e da necessidade de tornar obrigatória a vacinação antivariólica.

A imprensa, que inicialmente aprovou a indicação de Oswaldo Cruz para a direção da Saúde Pública, diante do projeto de reestruturação dos serviços manifestou-se contrária às proposições, lançando profundas críticas ao sanitarista e às suas novas idéias, como se pode constatar nos 
periódicos consultados no Acervo da Casa de Oswaldo Cruz (O Paiz, Gazeta de Notícias, A Notícia, Jornal do Commercio). Os jornais claramente favoráveis às medidas governamentais, como o Jornal do Commercio, criticaram a Diretoria de Saúde Pública, argumentando que as orientações assumidas por esse órgão não estavam completamente afinadas com a política do governo da União (Jornal do Commercio, 9/7/1903).

Figura 10 - Nota do dia. Tagarela (15/08/1904)

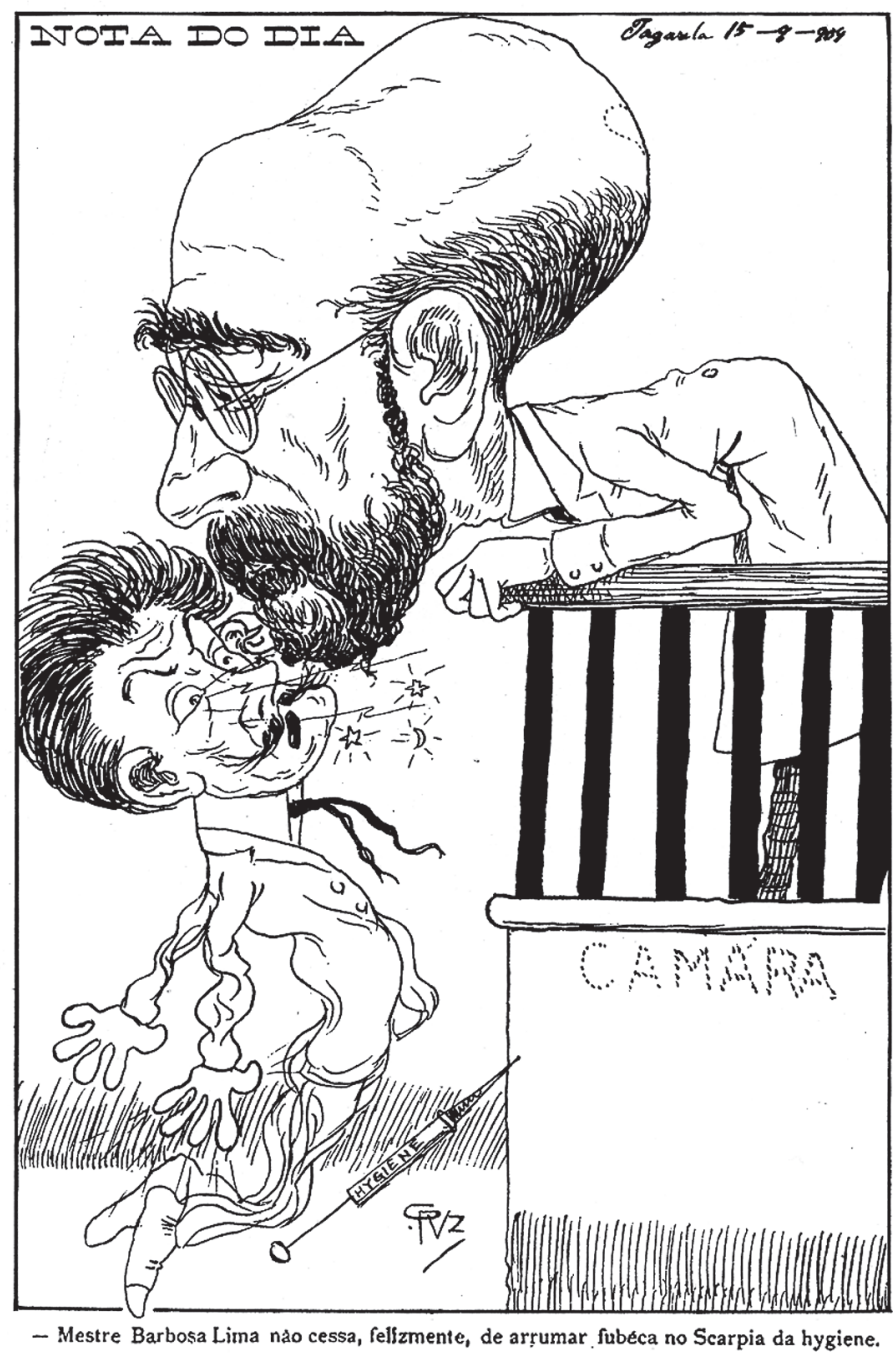

Fonte: Falcão (1971). 
Em meados de 1904, quando começou a tomar corpo uma epidemia de varíola, o governo e o diretor de Saúde Pública foram criticados por terem abandonado a profilaxia das doenças transmissíveis, voltando-se apenas para a febre amarela. Tal crítica, na realidade, não era específica desse momento. Tendo a febre amarela uma relação muito íntima com o padrão de desenvolvimento econômico, seu combate era sempre priorizado quando a política de governo transformava a saúde pública em uma de suas preocupações. O que tornava peculiar o ano de 1904 era a aplicação, para o seu combate, do método havanês, bastante criticado na ocasião. Sobre o assunto, Gil Vidal, em matéria no Correio da Manhã, acusou a Diretoria,

que absorvida inteiramente, na faina de destruir, no Rio de Janeiro, pelo método havanês, o germe da febre amarela, dentro de três anos, descura todos os mais deveres. Não lhe merecem a devida atenção nem a varíola, nem a tuberculose, nem outras moléstias que vitimam a população desta capital e de outros pontos da República. (Correio da Manhã, 22/6/1904)

Os chargistas de Tagarela não deixaram de se pronunciar e publicaram uma 'Conferência Sinistra' entre a varíola, a peste bubônica e a febre amarela, reproduzida mais adiante na Figura 13. Críticas a Oswaldo Cruz podem ser vistas nas Figuras 14 e 15.

A presença da epidemia gerou dúvidas quanto ao trabalho do Instituto Vacínico Municipal, que recebeu, ao mesmo tempo, veementes críticas e defesa da imprensa. Gil Vidal, na mesma matéria em que condenou o governo e o diretor da Saúde Pública, defendeu o Instituto, lembrando que a atribuição de evitar o contágio cabia à Diretoria Geral de Saúde Pública. Pedro Affonso, mais uma vez, investiu na manutenção de suas bases de apoio e convidou a imprensa para verificar o rigor seguido pela instituição na fabricação da vacina, o que foi amplamente divulgado (Tribuna, 8/8/1904).

Nesse contexto, a discussão sobre a obrigatoriedade da vacinação foi reativada e novamente sugerida em mensagem enviada pelo presidente da República ao Congresso, que a transformou em Projeto Legislativo.

Mais uma vez, a questão gerou polêmica e favoreceu longos e exaltados discursos na tribuna da Câmara. Embora estes se caracterizassem, em geral, pela oposição à obrigatoriedade ou propostas de obrigatoriedade parcial, o projeto foi aprovado conforme a proposição formulada pelo Senado. Segundo Afonso Arinos, a votação do projeto provocou sérias críticas dos adversários do governo por ter sido feita 'em bloco', sob a justificativa de haver inúmeras emendas (Melo Franco, 1973; Pôrto, 1985). Essa estraté- 
gia, certamente, possibilitou a aprovação do projeto, mesmo diante de toda a polêmica que gerou. A charge da Figura 16, mais adiante, ilustra tal situação.

Figura 11 - A varíola

\section{BRASIL - DOMINGO, 17 DE JULHO DE 1904 A TAFIOIA}

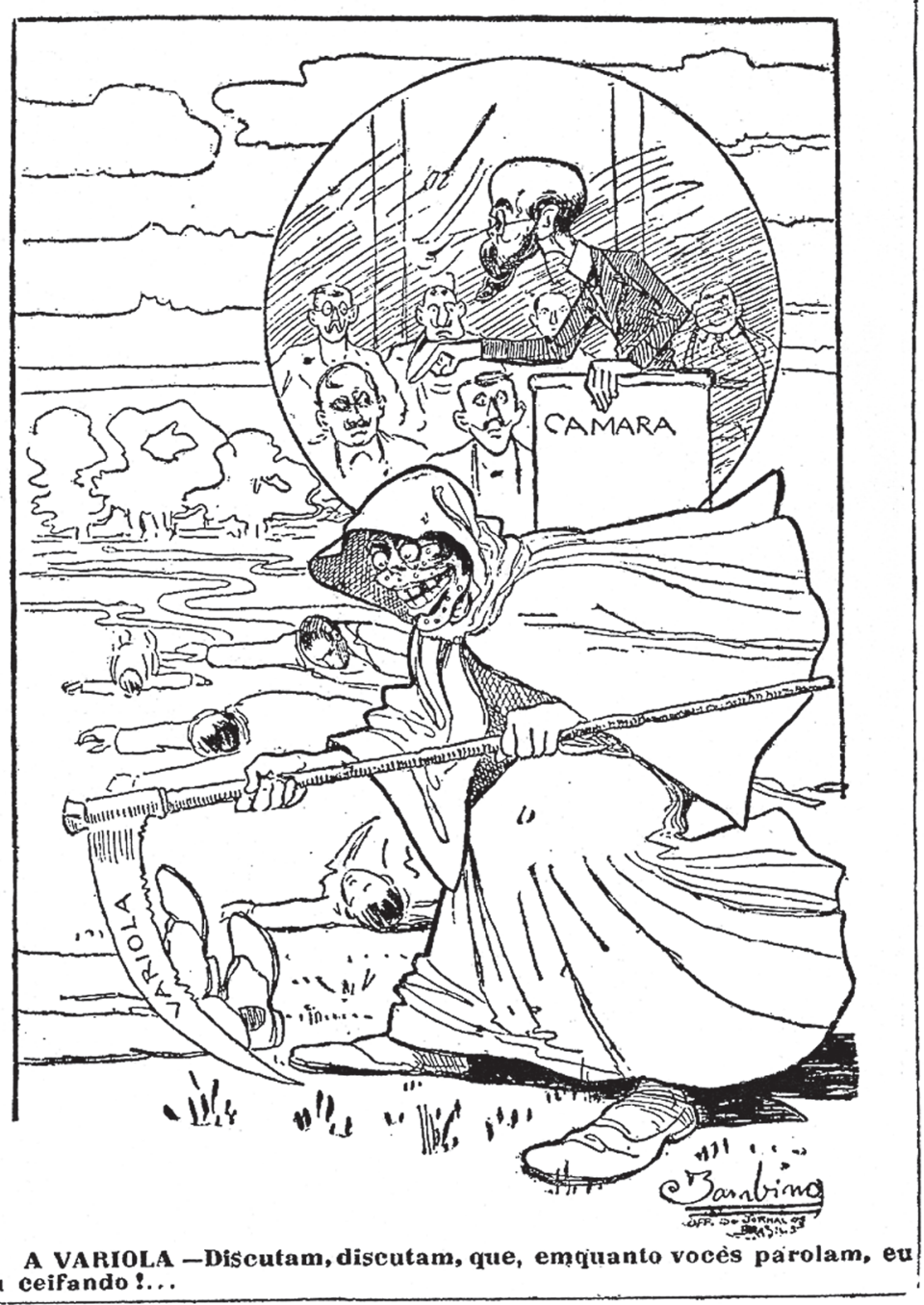

Fonte: Falcão (1971). 


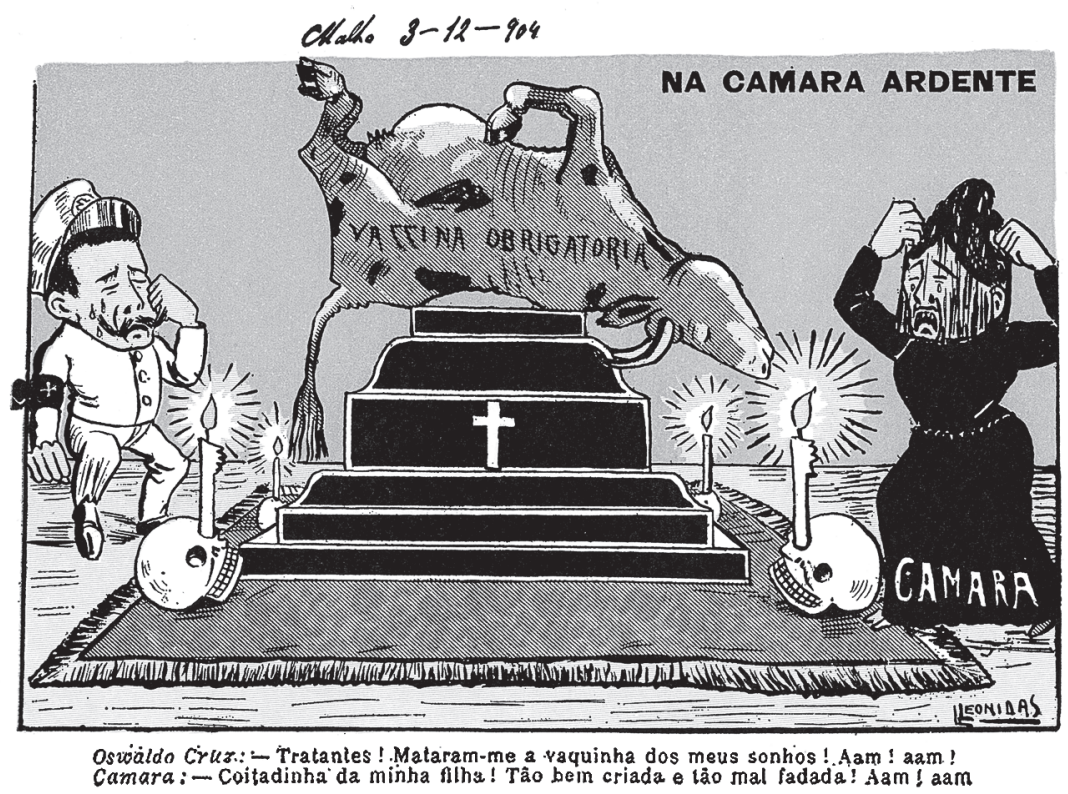

Fonte: Falcão (1971).

A Academia voltou a discutir o assunto e, por indicação de Seidl, Austregésilo e Costa Ferraz, encaminhou uma moção de apoio ao presidente da República com o seguinte texto: "congratula-se pela expressão clara e positiva contida na mensagem presidencial em relação à necessidade da vacinação e revacinação obrigatórias contra a varíola" (Anais da Academia de Medicina, sessão de 6/05/1904).

O intenso debate em razão da proposta de organização dos serviços de higiene, em particular da obrigatoriedade da vacina antivariólica, contou com grande participação do Apostolado Positivista, que se transformou no principal opositor a essas medidas. Teixeira Mendes e Bagueira Leal foram seus representantes de maior destaque (Pôrto, 1985). 
Figura 13 - Conferencia sinistra. Tagarela (25/08/1904)

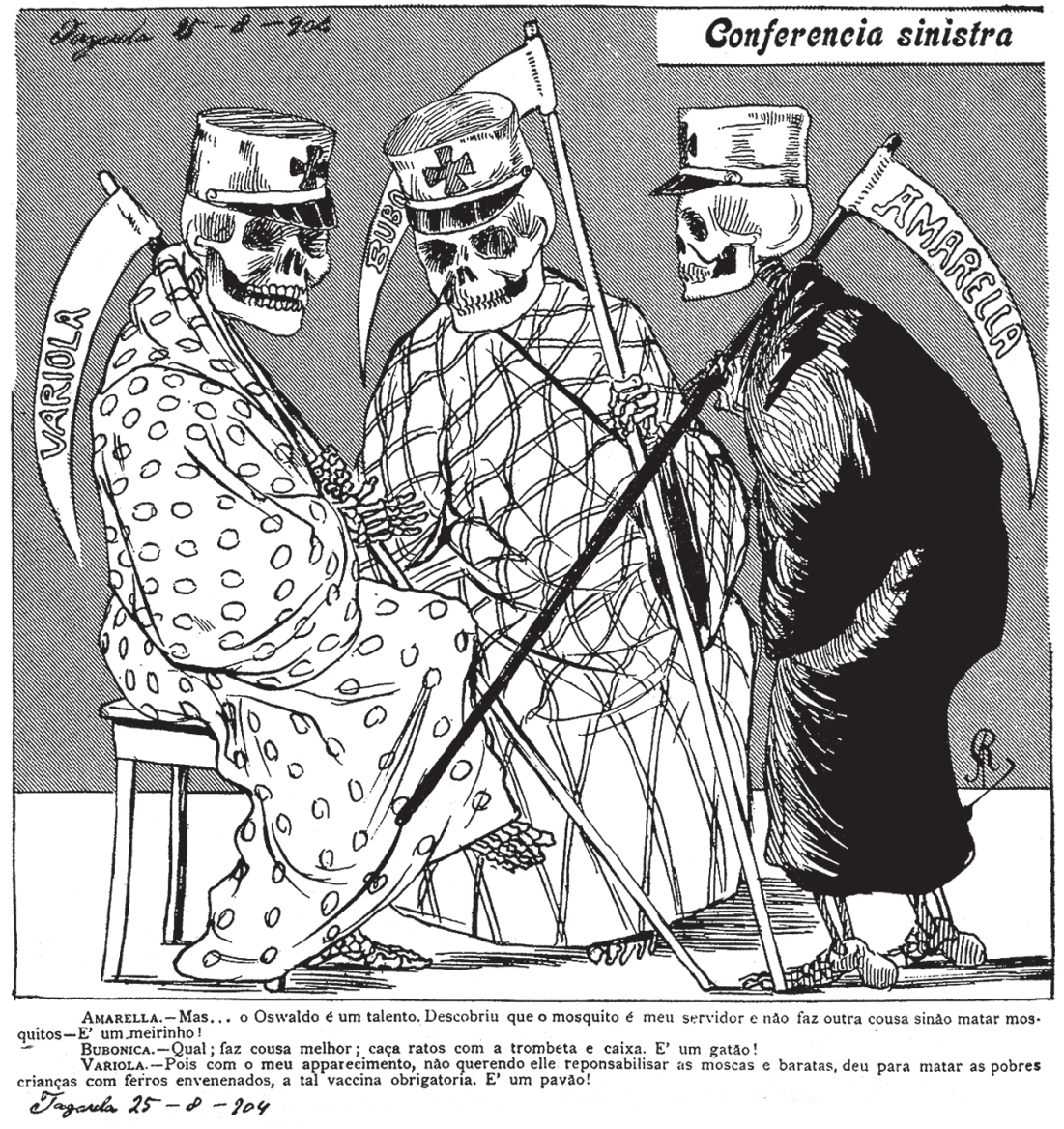

Fonte: Falcão (1971).

A divulgação da lei que regulava a obrigatoriedade da vacina funcionou como um catalisador das tensões sociais. Foi como um estopim em barril de pólvora já bastante aquecido pela grave situação socioeconômica em que se encontrava o país, levando a um conflito conhecido como Revolta da Vacina, que revirou a capital republicana em 1904. Essa revolta estava envolvida em um movimento social mais amplo, de descontentamento com as orientações governamentais, no qual se incluíam as medidas sanitárias indicadas por Oswaldo Cruz. A Liga contra a Vacinação, criada pelos membros do Apostolado Positivista, diante da aprovação da Lei de Obrigatoriedade, foi uma importante articuladora do movimento 
social emergente, fazendo, certamente, com que a manifestação fosse atribuída, pelo menos na sua denominação, à vacina obrigatória, apesar da amplitude de suas causas. A charge da Figura 17, mais adiante, faz alusão à Revolta da Vacina. ${ }^{13}$

Apesar de promulgada, a legislação que regulava a obrigatoriedade da vacina não foi implementada devido à reação social. Posteriormente, no entanto, sua aplicação foi reclamada, certamente após a constatação da eficácia das medidas sanitárias propostas por Oswaldo Cruz diante da febre amarela.

Para Pedro Affonso, a reação popular à Lei da Vacinação Obrigatória proporcionou um decréscimo fortíssimo na procura pela vacinação, "reduzindo à letra morta a lei e o regulamento respectivo e fazendo-nos retrogradar de muitos anos na adoção da vacinação e revacinação". As vacinações, que em 1904 atingiram aproximadamente 21 mil doses, em 1905 chegaram a 4.500 aplicações (Franco, 1917: 45-55).

Oswaldo Cruz tinha como característica não se pronunciar publicamente e assim se manteve mesmo diante de todas as críticas sobre sua conduta frente à higiene. Sua resposta ao episódio da Revolta da Vacina foi colocar o cargo à disposição do ministro do Interior J. J. Seabra, reafirmando, assim, a crença e a segurança nas orientações que vinha adotando. Vários higienistas e políticos, como Carlos Seidl, Plácido Barbosa e Azevedo Sodré, entre outros adeptos das orientações assumidas por Oswaldo Cruz serviam-lhe de base de sustentação política, além da que angariara entre os políticos na Câmara, que defenderam publicamente as ações da Diretoria de Saúde Pública em diversos fóruns de debate. Entre a categoria médica, a Revista Médico-Cirúrgica do Brasil, de propriedade de Carlos Seidl, e o Brazil Médico, periódico de Azevedo Sodré, eram importantes espaços de divulgação e legitimação da higiene no Brasil nesse momento, nitidamente partidários das medidas indicadas por Oswaldo Cruz. 
Figura 14 - Ao "Heroe dos mosquitos". Revista da Semana (1904)

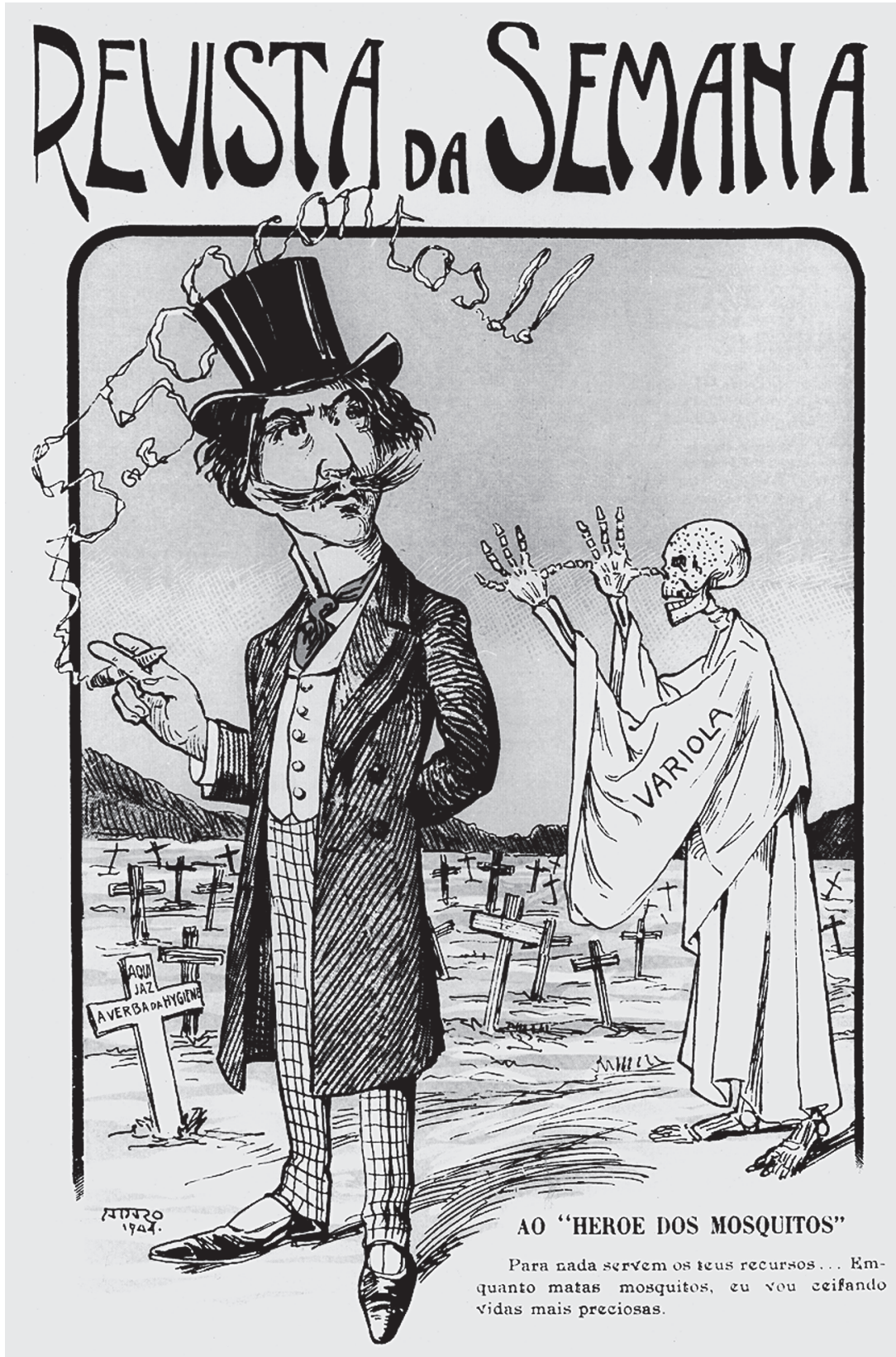

Fonte: Falcão (1971). 
Figura 15 - As crianças. Tagarela (18/08/1904)

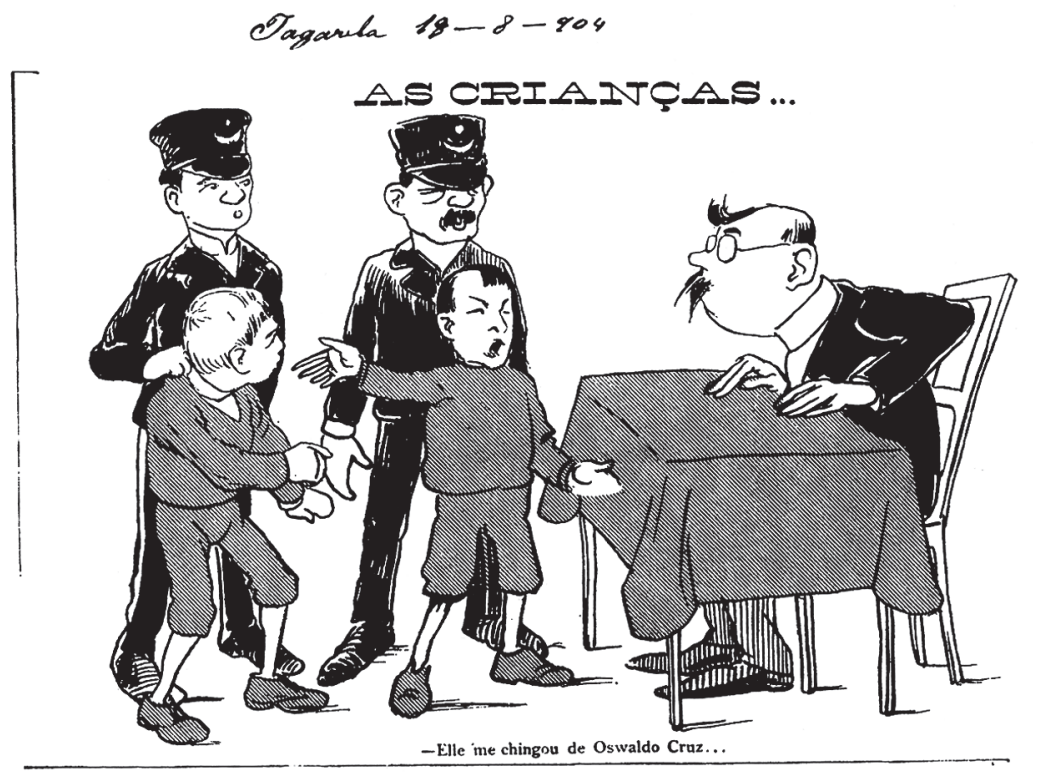

Fonte: Falcão (1971).

Após o período conturbado de 1904, percebe-se nova tentativa de Oswaldo Cruz de subordinar o Instituto Vacínico Municipal ao Instituto Soroterápico, testando o prestígio e a força política que Pedro Affonso detinha. Em continuidade ao projeto de estruturação dos serviços de higiene aprovado em 1904, Mello Mattos - porta-voz de Oswaldo Cruz na Câmara dos Deputados - apresentou uma proposta de reorganização do Instituto Soroterápico Federal para ampliar suas atividades e garantir a autonomia técnica e orçamentária.

Em resposta, as Comissões de Saúde Pública e Finanças da Câmara elaboraram um substitutivo que diminuía o orçamento requerido para o 'novo' Instituto e excluía, mais uma vez, a vacina antivariólica da proposta original, mantendo a produção desse imunoterápico no Instituto Vacínico Municipal. Além disso, a Comissão de Saúde Pública propôs alterar o nome do órgão, que passaria de Instituto de Medicina Experimental de Manguinhos para Instituto de Patologia Experimental. Essa proposta, elaborada pela Comissão na Câmara, no entanto, acrescentava ao Instituto uma atribuição que o projeto original não previa: a fiscalização dos imunoterápicos importados. Isto significou mais um passo na 
direção do controle que Oswaldo Cruz desejava ter sobre todos os imunoterápicos, inclusive indiretamente sobre a vacina antivariólica. $\mathrm{O}$ barão referiu-se à medida proposta como uma atitude 'leonina' da parte de Oswaldo Cruz, que tinha como estratégia ir conquistando, aos poucos, controle pleno sobre todos os imunoterápicos.

Figura 16 - Gazeta (04/10/1904)

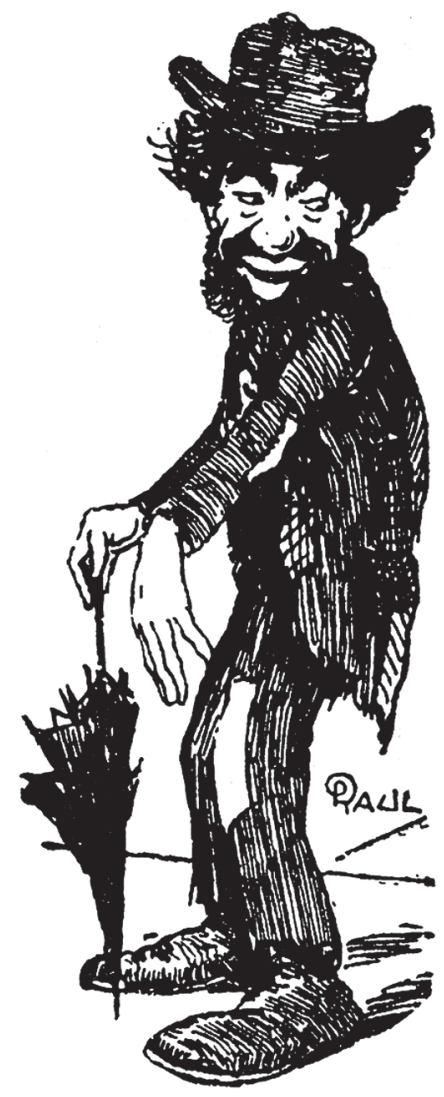

- Inté parece que sou o profecto da vaccina. com tanta emenda...

Fonte: Falcão (1971). 
Figura 17 - Guerra vaccino-obrigateza. O Malho(29/10/1904)

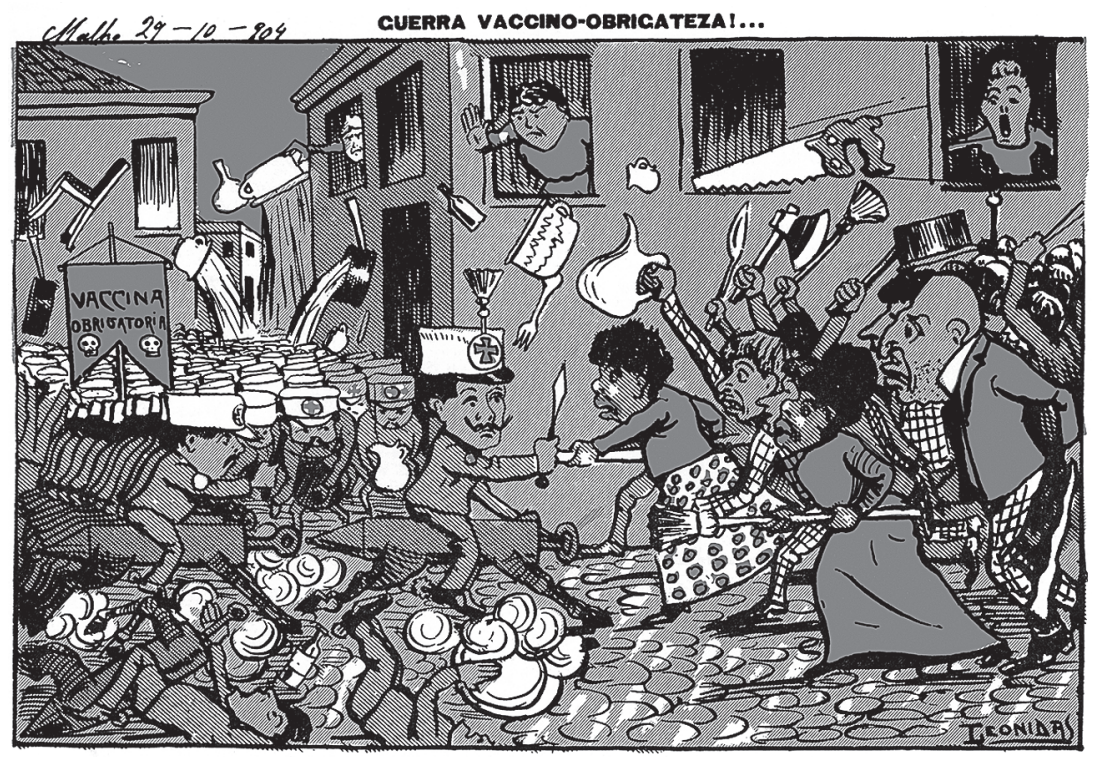

Espectaculo para breve nas ruas desta cidade. Oswaldo Cruz, o Napoleáo da seringa e lanceta, á frente das suas forcas obrigatorias. sera recebido e manifestado com denodo pela população. O interessante dos combates deixará a perder de vista o das batalhas de flores e - da guerra russo-japoneza E veremos no flm da festa quem será o vaccinador á força !.

Fonte: Falcão (1971).

No Senado, várias outras emendas foram propostas ao substitutivo da Câmara. Quando este retornou e foi apreciado pelas Comissões, estas aconselharam sua aceitação, justificando, como publicado nos Anais da Câmara dos Deputados de 18 de novembro de 1907, que as emendas não alteraram "a essência do mesmo projeto".

O substitutivo encaminhado pelo Senado detinha-se, em geral, em modificações no texto e não propriamente no conteúdo, no qual poucas alterações foram formuladas. Uma delas referia-se ao exercício da fiscalização atribuído ao Instituto de Manguinhos, ampliado aos fabricantes de vacinas e soros particulares, excetuando-se os "Institutos oficiais dos estados e Distrito Federal, salvo quando alguma ocorrência for de ordem a gerar suspeitas que julgar indispensáveis para as suas investigações" (Franco, 1917). Com essa ressalva no texto, o Instituto Vacínico Municipal continuou isento da fiscalização rotineira, por ser considerado um instituto oficial.

Mais uma vez, Oswaldo Cruz investiu em direção à vacina antivariólica, sendo novamente frustrado por Pedro Affonso, que conseguiu manter seu Instituto longe da órbita de Manguinhos. Ainda não foi esse projeto que 
viabilizou a autonomia do Instituto, conforme requeria Oswaldo Cruz, principalmente no que dizia respeito a questões orçamentárias.

Apesar de não incorporar a produção da vacina antivariólica ao Instituto que dirigia e de ter, em 1903, desencadeado um intenso processo de rejeição às suas medidas, Oswaldo Cruz acabou conquistando um espaço político que colocava Pedro Affonso em constante estado de alerta, ameaçando o monopólio da produção da vacina que conseguira obter.

Com o controle da febre amarela no Distrito Federal em três anos, como Oswaldo Cruz havia acordado com o governo republicano em sua proposta de reestruturação dos serviços em 1904, o sanitarista de Manguinhos reunia louros para a construção de sua imagem de mito. Nesse sentido, um momento decisivo foi a medalha de ouro que o Instituto de Manguinhos recebeu na Exposição Internacional de Higiene em 1907. Certamente, esses foram troféus importantes para o reconhecimento social de Oswaldo Cruz, consagrado até os dias de hoje como o símbolo da ciência biomédica brasileira. ${ }^{14}$

\section{9:}

\section{Pedro Affonso busca manter a calmaria}

A renovação do contrato do Instituto Vacínico com a prefeitura, realizada em 1904, era válida por sete anos, prazo que findaria em 1912. Porém, ainda em 1909, Pedro Affonso, com o intuito de garantir a renovação, armou um estratagema para antecipá-la. Solicitou do governo municipal autorização para realizar obras na fachada do Instituto, incluindo nessa solicitação a renovação do contrato, que começaria, segundo a proposta, a vigorar somente a partir de 1912. Antevendo as conseqüências que poderiam advir da situação imprecisa que se configurou, Pedro Affonso, a partir da epidemia de varíola que marcou a capital republicana, em 1908, com um dos mais graves surtos de sua história, tentou mais uma vez sustentar-se antes que a ameaça se consolidasse de fato.

Essa conjuntura, embora não fosse ameaçadora para o Instituto Vacínico, como havia ocorrido em 1904 e em 1907, tinha algumas peculiaridades. Na realidade, tratava-se de um momento de instabilidade para os serviços de saúde como um todo e para seus dirigentes, quando Oswaldo Cruz, ainda na direção da Saúde Pública Federal, seria alvo de severas críticas. O recente surto de varíola desencadeou um novo processo de 
discussão sobre a obrigatoriedade da vacinação como uma medida higiênica de relevo. Apesar de causar menos polêmica do que em 1904, o tema ainda era motivo de desavenças.

A posição de Oswaldo Cruz diante do surto está registrada no Relatório Anual de Atividades da Diretoria de Saúde Pública, que prescreve a vacinação obrigatória como a única medida capaz de evitar outros surtos. Nesse relatório, o sanitarista expressou-se por meio de um parecer que se tornou clássico com relação à varíola. Dizia que "a Diretoria confiante aguarda que o governo se digne de mandar que a varíola seja extinta e nesse dia ela o será" (Revista Médico-Cirúrgica, 1908: 328). ${ }^{15}$

O cumprimento da lei de obrigatoriedade da vacinação era de responsabilidade do diretor da Saúde Pública, mas o governo não se arriscou a impor essa medida, certamente com receio de reproduzir o movimento oposicionista de 1904.

Diante da posição do diretor da Saúde Pública e da inação governamental, o senador Barata Ribeiro exigiu informações do governo sobre o que estava sendo feito com relação às vítimas da epidemia reinante. Em sua opinião, o controle da doença deveria ser feito por meio do isolamento dos casos confirmados e dos suspeitos da doença, em aberta oposição às idéias de Oswaldo Cruz, que dava à vacinação maior peso profilático. Apesar de centrar as perspectivas de controle da doença na vacinação, Oswaldo Cruz ampliou o serviço hospitalar com a criação de um hospital no Engenho de Dentro e com a reabertura do Hospital Paula Cândido, que seria utilizado para o tratamento de variolosos.

A posição assumida pelo senador desencadeou uma intensa polêmica, que o incentivou a elaborar um projeto de lei em que destacava a necessidade da ampliação do isolamento hospitalar. Quanto à vacinação - que julgava ser uma atitude voluntária -, defendeu sua expansão, sugerindo que o governo criasse postos vacínicos e implementasse a vacinação domiciliar quando requisitada por seus responsáveis.

Apesar de a proposta de Barata Ribeiro não ter sido transformada em lei, as atividades, até então desenvolvidas somente por Pedro Affonso no Instituto Vacínico Municipal, foram, nessa ocasião, estendidas para a Diretoria de Saúde Pública. Pedro Affonso, principalmente em épocas de surto, costumava instalar postos vacínicos em algumas estações ferroviárias e na Santa Casa da Misericórdia.

Mesmo diante da acirrada polêmica gerada pelo senador Barata Ribeiro, Oswaldo Cruz não se manifestou publicamente, de modo coerente 
com sua postura perante a embates dessa natureza. Contudo, em correspondência ao senador Antônio Azeredo, que o consultara sobre a questão, ele se mantinha aferrado às suas idéias, afirmando que "as medidas contidas no projeto apresentado pelo Exmo. Sr. Dr. Barata Ribeiro nada virão acrescentar à eficácia daquelas já postas em prática pelo governo”. Isto é, Oswaldo Cruz continuava, impassivelmente, a defender a vacinação obrigatória (Fernandes \& Portela, 1989).

Os debates sobre a questão ocasionaram manifestações de apoio a Oswaldo Cruz por parte de alguns médicos e higienistas, como, por exemplo, Carlos Seidl e Plácido Barbosa. No âmbito do Senado, Antônio Azeredo e Érico Coelho assumiram a sua defesa. A Revista Médico-Cirúrgica também o apoiou, afirmando que "o governo tem sido incansável nas medidas de salvação", citando a reabertura do Hospital Paula Cândido, em Jurujuba, para servir aos convalescentes saídos do Hospital São Sebastião, e também a abertura de um hospital no Engenho de Dentro para melhor servir aos moradores do subúrbio, aproveitando as instalações de uma ex-fábrica de louças (Revista Médico-Cirúrgica, 1908).

Em torno do surto de 1908 havia dois tipos de discussão: o primeiro, de âmbito político-administrativo, trazia críticas quanto à condução política geral e à priorização da febre amarela em detrimento das outras doenças transmissíveis, dentre elas a varíola; o segundo tipo de discussão, de caráter técnico, tratava do papel do hospital de isolamento e/ou da vacinação como medidas a serem assumidas, ou não, ante uma epidemia.

Uma charge de Loureiro, publicada em $O$ Malho, aponta o espanto das autoridades governamentais diante da 'Varíola' e a manutenção da opinião de Oswaldo Cruz quanto à vacinação obrigatória (Figura 18). $O$ Malho publica também um texto de apoio à vacinação ilustrada por uma figura humanizada da varíola, com erupções, esquálida e envolta pela morte (Figura 19).

Essas questões e a mudança de governo certamente motivaram o comportamento açodado de Pedro Affonso quanto à renovação do contrato do Instituto Vacínico Municipal com o município, já que em nível federal a situação era imprevisível. Apesar das mudanças que marcaram o período no que diz respeito aos serviços sanitários, o Instituto Vacínico não foi atingido, tendo sua sobrevivência garantida com a renovação do contrato. 
Figura 18 - Gargalhada da morte. O Malho(03/10/1908)

GaRgalHadA DA MORTE

"A peste vermelha está matando 300 pessoas por semana e alé á penultima já tinha "A peste vermelha estả matand
levado 4 483 vidas." -(Dos jornaes).

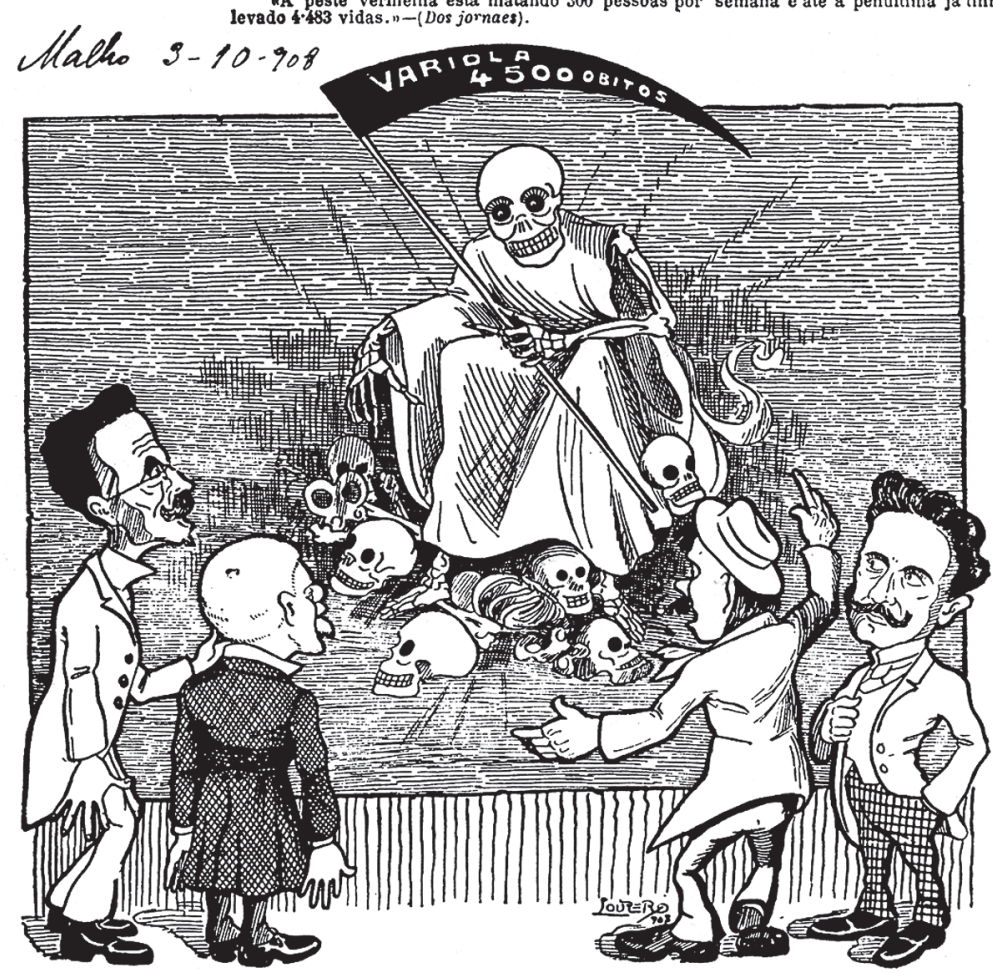

Penna: - Chi !!... Que horror :

Prefeito: - Que horror! Chi... que podia ser perfeitamente jurulada no principio, ha seis mezes, quando mava 20 pessoas por mezima e nao foi por papricho ou relaxamento e que agora se ri dos responsaveis!... Nao sei para que pago impostos esfolladores! Talvez para isto : para ver bestificada a gente que me governa :

Osicaldo Cruz: - Sem yaccina obrigatoria, nada posso fazer ...

A variola: - Nada, hein? Ah! ah! ah! ah!!!...

Fonte: Falcão (1971).

Pedro Affonso, alguns anos mais tarde, traduzindo certa tranqüilidade quanto ao período e refletindo sobre os momentos de tensão, afirmou, no Relatório de Atividades do Instituto Vacínico Municipal de 1915, que

por várias vezes tem-se tentado desorganizar o nosso Instituto, tão paciente e tão perfeitamente organizado, para entregar ao Instituto de Manguinhos, que tem tantos ramos para exercer sua atividade, a cultura e preparo da vacina jenneriana. O bom senso, porém, tem predominado e o nosso estabelecimento tem passado incólume até agora.

A lei que regia a acumulação de cargos públicos entrou em vigor, e Oswaldo Cruz, que ocupava dois cargos em instituições públicas, optou pela 
permanência na direção do Instituto Oswaldo Cruz, direcionando os trabalhos de Manguinhos, nesse momento, para fora da cidade e dirigindo sua atenção para o interior do país.

Figura 19 - Ao povo. O Malho-agosto/1908

O MALHO
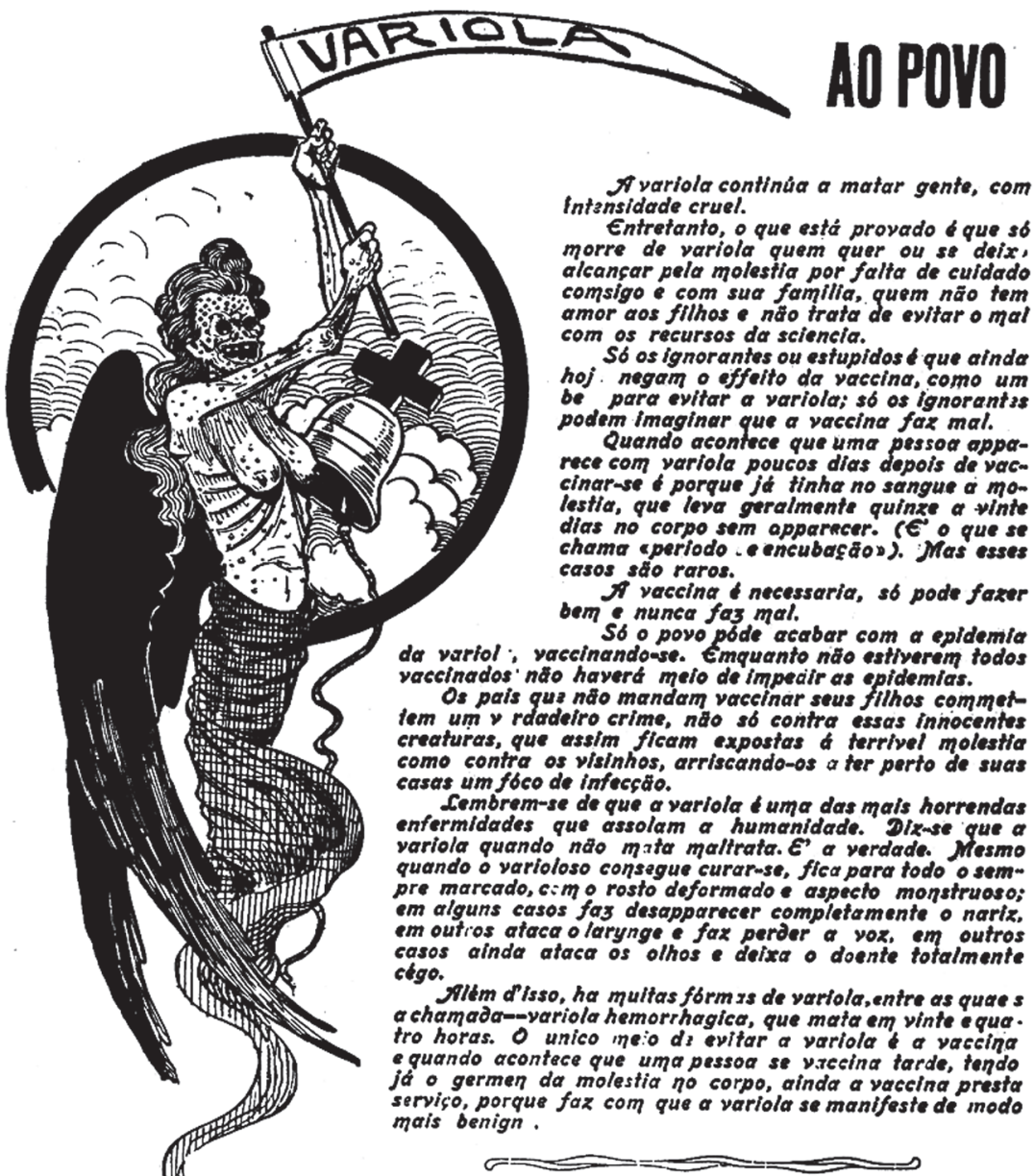

E" sbsolutamente exacto o que acima dissemos; mas tambem certo q110 is auloridades de hyglene estao se mostrando singularmente

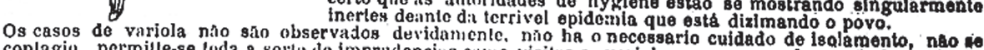

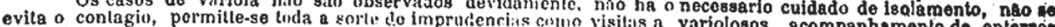

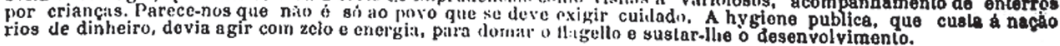

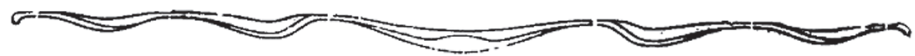


Ocorreu uma situação de calmaria, na qual o Instituto Vacínico permaneceu durante muitos anos. A inexistência de propostas inovadoras no sentido da reorganização dos serviços de saúde e a ausência de concorrência na produção da vacina permitiram sua estabilidade.

Esse quadro pode ser percebido perante um fato bastante diverso da situação observada em 1904 e 1907. Em consulta a Oswaldo Cruz em 1912, o ministro do Interior aventou mais uma vez a hipótese de transferir para o Instituto Oswaldo Cruz o Instituto Vacínico Municipal. Oswaldo Cruz respondeu que a medida seria inconveniente, já que o Instituto Municipal vinha funcionando 'regularmente', não havendo 'razão plausível' para interromper suas atividades. ${ }^{16}$

Oswaldo Cruz, nesse momento, vinha direcionando sua atenção para fora do Distrito Federal, onde a vacina antivariólica não era uma questão prioritária para suas pesquisas, dedicadas às doenças endêmicas características da zona rural e do norte do país. As críticas da imprensa a seu posicionamento podem ser vistas tanto nas charges como em alguns textos de jornal. O Malho publica: "Lá anda o Sr. Oswaldo Cruz pelos igarapés do Pará a colecionar mosquitos e a comer pirarucu, enquanto por aqui os seus mata-mosquitos se transformam em carrascos no tal serviço de expurgo, pela forma brutal com que o fazem (...)". Sobre isso, a Gazeta estampou uma charge (Figura 20, na próxima página).

Iniciava-se um período que Benchimol caracteriza como o naufrágio da reforma de Oswaldo Cruz na capital. O novo presidente da República, Hermes da Fonseca, mesmo mantendo um representante de Manguinhos na direção dos serviços de higiene federal, adotou medidas contrárias às indicadas por Oswaldo Cruz, provocando a exoneração do então diretor, Henrique de Figueiredo Vasconcelos, após dois anos de exercício da função (Benchimol, 1990: 51).

Com a saída de Figueiredo de Vasconcelos e a rápida passagem de Pacheco Leão pela Diretoria Geral de Saúde, assumiu a direção dos serviços de higiene Carlos Seidl, que até então dirigia o Hospital São Sebastião. Sua gestão, iniciada em 1912, caracterizou-se por uma tentativa de dar continuidade ao projeto oswaldiano de higiene. Nesse mesmo ano, procedeu à unificação de alguns serviços, com a criação da Inspetoria dos Serviços de Profilaxia a partir da fusão das Inspetorias de Isolamento, de Desinfecção e de Febre Amarela (Relatório da Diretoria Geral de Saúde Pública, 1913). 
Seidl enfrentou um período de grande turbulência, sendo a ele dirigidas severas críticas quanto à situação sanitária do país. Suas propostas visavam à remodelação dos serviços de saúde pública da União. Manteve as bases que nortearam a legislação de 1904, buscando dar-lhes caráter definitivo - já tentado por Oswaldo Cruz em 1908 - quanto às questões orçamentárias e administrativas. Assumiu destaque na proposta o fortalecimento da polícia sanitária dos portos, viável nessa conjuntura política em que o governo Hermes promoveu intervenção em vários estados, episódio conhecido como "as salvações". ${ }^{17}$

Figura 20 - Gazeta $(1 / 10 / 1905)$
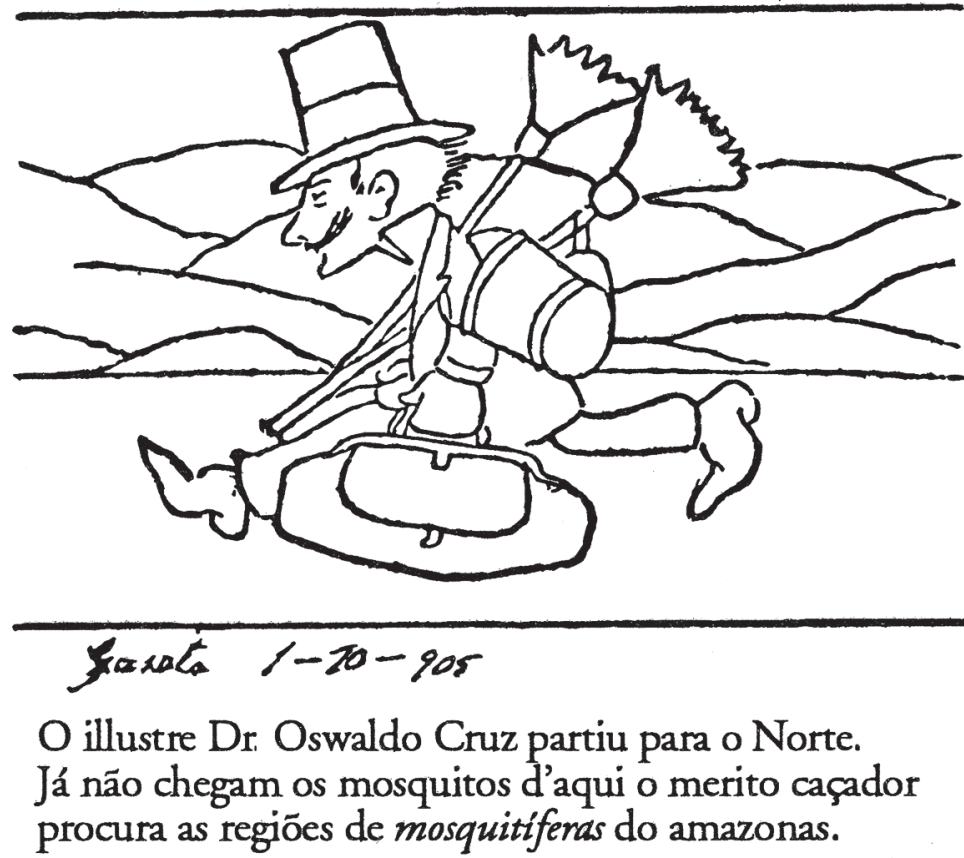

Fonte: Falcão (1971).

Apesar de suas intenções, a reformulação não imprimiu aos serviços a eficiência necessária diante do grave quadro de morbi-mortalidade que se desenhava com o agravamento das condições de vida e saúde da população que marcava esse período. 
Em 1916, Carlos Seidl, ainda na direção da Higiene Federal, desiludido quanto aos métodos persuasivos ou voluntários de que era partidário até então, procurou 'incitar' o governo a regulamentar a vacinação, para intensificar o uso da vacina antivariólica. Para isso, solicitou que o delegado de Saúde Leonel da Rocha formulasse um projeto que descrevia como "liberal e consentâneo com os nossos hábitos sociais". Segundo Seidl, o projeto desagradou o ministro Maximiliano, que "não admitiu que se tratasse do assunto". Apesar de ser partidário da regulamentação da vacina, o ministro anulou a proposta, pois, segundo ele, esta esbarrava em seus interesses político-partidários no Rio Grande do Sul, onde mantinha suas bases políticas (Revista Médico-Cirúrgica, 1919: 536).

Certamente, o movimento de 1904 ainda continuava a aterrorizar o governo republicano, apesar da avaliação de Seidl de que o povo e a imprensa já estavam preparados para aceitar a regulamentação.

Quanto ao Instituto Vacínico Municipal, não nos foi possível localizar todos os relatórios anuais das atividades desenvolvidas por essa instituição. Supomos que Pedro Affonso não os elaborasse com regularidade. Porém, de acordo com os relatórios do período 1913-1917, pode-se perceber que ocorreram poucas mudanças institucionais. Em 1913, ampliou-se de três para quatro o quadro de vacinadores, ao qual foi incorporado Paulo Affonso Franco, filho de Pedro Affonso. Vale assinalar que, em 1909, quando negociou a renovação do contrato, Pedro Affonso solicitou a redução do número de vacinadores, argumentando que o Instituto apresentava excesso de pessoal. Jorge Affonso, outro filho de Pedro Affonso, também foi incorporado ao quadro técnico do Instituto Vacínico - não como vacinador e, sim, como auxiliar, atuando como substituto de algum vacinador quando em período de licença, o que nessa época ocorria com certa regularidade. A incorporação dos filhos ao quadro de funcionários nos sugere o entendimento de que Pedro Affonso via 'seu' Instituto como uma organização bastante particular, mais ainda, como um empreendimento familiar, seguindo modelos tradicionais de organização institucional.

De acordo com o relatório de 1913 - reforçando nossa opinião anterior -, Pedro Affonso reivindicou a extinção do cargo de vice-diretor, criado em 1897, afirmando que estes "são antagonistas naturais dos diretores", podendo, por qualquer divergência de opinião, estabelecerse a 'desordem' no serviço. Assim, propôs apenas a possibilidade de indicação, com remuneração prevista, de um substituto para as ocasiões em 
que se ausentasse. Essa última atitude é bastante típica de Pedro Affonso, que não tolerava a descentralização do poder, como observamos por ocasião de seu trabalho no Instituto Soroterápico Federal (Instituto Vacínico Municipal, 1913; Fernandes, 1989).

No relatório de atividades do Instituto Vacínico Municipal de 1914, verificamos outro episódio interessante relacionado à instituição. Em 1913, com o aumento de casos de varíola em Minas Gerais, o governo estadual requisitou ao Instituto Vacínico Municipal um maior número de doses de vacinas. Apesar do contrato de 1895 com o governo da União, que subvencionava a fabricação de vacina também para outros estados, Pedro Affonso exigiu uma remuneração extra, provinda dos cofres mineiros, estabelecendo um contrato que vigorou até 1915 (Instituto Municipal, Relatório de Atividades, 1914).

É importante destacar que existia em Minas Gerais, desde 1907, um Instituto filial de Manguinhos, onde se produzia e vendia a vacina antivariólica. Pedro Affonso condenava a comercialização da vacina por parte desse Instituto, contrária à sua prática de cessão do produto em troca de subvenção, o que para ele não significava comércio. Esse episódio subsidiou a crítica formulada por Arthur Neiva em 1917, quando novamente se indicou a necessidade de reestruturar os serviços de higiene da União, acusando Pedro Affonso de vender vacinas aos estados, rompendo o acordo de gratuidade estabelecido desde o primeiro contrato do Instituto.

Em 1916, para marcar a comemoração dos trinta anos da vacina animal no Brasil, Pedro Affonso redigiu um longo texto sobre suas atividades e o Instituto Vacínico Municipal, recorrendo à correspondência enviada durante esse período por personalidades que reconheciam e enalteciam o trabalho que realizava (Relatório dos Trabalhos do Instituto Vacínico Municipal, 1916). ${ }^{18}$

Certamente, a idade avançada motivou-o a registrar seus feitos, buscando também assegurar a continuidade de seu trabalho por meio da incorporação de seus filhos ao Instituto, tornando-os, dessa forma, seus legítimos herdeiros científicos.

Apesar das precauções que tomou, Pedro Affonso não foi capaz de prever os acontecimentos futuros, que constituiriam uma ameaça real à sua manutenção à frente do Instituto Vacínico Municipal. É o que veremos a seguir. 


\section{Instituto Vacinogênico Federal: a derrota de Pedro Affonso}

O contrato de manutenção do Instituto Vacínico Municipal - assinado em 1909, para vigorar a partir de 1912 - tinha o término previsto para 1921. Porém, não chegou a ser cumprido integralmente. A discussão intensa travada a partir de 1918, especialmente após o surto de gripe espanhola, colocou em pauta a necessidade de reestruturação dos serviços de saúde com base no diagnóstico que concluía pela falência da organização estatal no setor. Essa discussão foi decisiva para a vacina antivariólica, pois novamente se colocava a questão da centralização.

Além disso, tecnicamente, o Instituto Vacínico vinha recebendo críticas como a formulada por Neiva, segundo a qual "durante muito tempo a vacina preparada naquele Instituto era excelente, porém isto já não se poderá dizer hoje..." Neiva criticava também o fato de a Diretoria Geral de Saúde Pública, no Rio de Janeiro, ser "a única em todo o mundo a não possuir um Instituto Vacinogênico sob a sua dependência”, em contraposição ao grave quadro epidemiológico da varíola no país (Neiva, 1917). ${ }^{19}$

Neiva apontava mais uma questão que, para ele, justificava a incorporação do Instituto Vacínico ao âmbito federal. Referia-se ao fato de estarem sendo vendidas vacinas aos demais estados e municípios, conforme o episódio anteriormente descrito relativo à venda de vacina ao estado de Minas Gerais.

A eleição de Epitácio Pessoa, em 1919, para a Presidência da República significou um passo importante no sentido do atendimento às reivindicações encaminhadas por médicos e políticos com vistas à reestruturação dos serviços de saúde. Em setembro de 1919, ele encaminhou, em mensagem presidencial ao Congresso Nacional, a proposta de criação de um ministério da Saúde, apresentada pelo médico e deputado Azevedo Sodré em agosto de 1918. Tal proposta expressava o consenso de alguns representantes da categoria médica, que, por intermédio da Academia Nacional de Medicina, já haviam formulado proposta semelhante no fim de 1917. Ela determinava a criação de um ministério da Saúde Pública em substituição à Diretoria Geral de Saúde Pública, utilizando como base o diagnóstico formulado por Belizário Pena e Arthur Neiva quanto à saúde no Brasil. Belizário e Neiva foram responsáveis pelo desencadeamento da campanha de saneamento rural, representada 
pela criação da Liga Pró-Saneamento do Brasil, em 1918. Para esse movimento, a saúde era uma questão fundamental à construção da nação. ${ }^{20}$

Os deputados Azevedo Sodré e Teixeira Brandão polarizavam a discussão sobre a proposta de criação do Ministério. Sodré defendia enfaticamente o poder do governo central sobre o nível local, e Brandão, por outro lado, coerente com as idéias que defendia desde 1904, argumentava a favor da autonomia dos estados na gerência dos serviços.

Esse debate encontrou campos férteis de discussão em outros fóruns. A Academia de Medicina, as sociedades médicas, as faculdades de medicina, a imprensa e alguns outros profissionais, por meio de publicações, manifestaram-se em apoio à idéia de centralização dos serviços no âmbito da União, embora a questão não tenha chegado a um consenso.

Apesar de a obrigatoriedade da vacina não ter sido uma questão central na discussão que norteou a criação do Departamento Nacional de Saúde Pública, o receio da implantação da obrigatoriedade do uso da vacina antivariólica transparece, por exemplo, no discurso de Domingos Mascarenhas, quando defende que deveria "ser respeitada a liberdade de crença dos cidadãos não só quanto à terapêutica, como também quanto às medidas profiláticas”. Ele acrescentou ainda, como registrado nos Anais da Câmara de 18 de novembro de 1919, que "a intervenção grosseira da polícia sanitária (...) pela força das doutrinas médicas produz a revolta e a desordem material".

No final da discussão que percorreu os anos de 1918 e 1919, a proposta vencedora, expressando o intenso processo de negociação vivenciado principalmente no final desse período, criou o Departamento Nacional de Saúde Pública. ${ }^{21}$

A proposta da centralização e ampliação dos serviços de higiene em torno do Departamento Nacional de Saúde Pública incluía a vacina antivariólica e o Instituto Vacínico Municipal do Rio de Janeiro. O diagnóstico do novo diretor da Saúde Pública Federal - Carlos Chagas quanto a este Instituto não foi diferente do elaborado anteriormente por Neiva. Acrescentou ele ainda que a instituição funcionava em um prédio pequeno, que não comportava a ampliação que se desejava imprimir à produção da vacina e que a prefeitura afirmava não ter condições financeiras de subvencionar uma demanda maior.

Como conseqüência das críticas ao Instituto Vacínico Municipal e da nova articulação política que marcou a criação do Departamento Nacional 
de Saúde Pública, o Instituto Vacínico foi incorporado ao Instituto Oswaldo Cruz, como órgão federal. Dessa forma, o Instituto de Manguinhos assumia a produção da vacina antivariólica, pleiteada desde 1904 por Oswaldo Cruz, por intermédio do instituto que passou a ser denominado Instituto Vacinogênico Federal.

O deslocamento do Instituto Vacínico Municipal da esfera municipal para a federal foi marcado por uma complexa negociação, que apresentou dificuldades de entendimento na viabilização da mudança. Por um lado, Pedro Affonso não tinha a menor intenção de 'vender' seu Instituto; por outro, a prefeitura e o governo federal não queriam indenizar Pedro Affonso por quebra de contrato, conforme estava indicado legalmente. ${ }^{22} \mathrm{~A}$ prefeitura acabou efetuando o pagamento da indenização, inclusive a parcela que cabia ao governo federal. O Instituto permaneceu alojado no prédio da rua do Catete, mantendo-se o pagamento de um aluguel mensal aos proprietários até que fosse construído um prédio próprio para a sua instalação nos terrenos de Manguinhos.

Pedro Affonso faleceu logo em seguida, dois meses após ter sido assinada a transferência da instituição (setembro de 1920). Seus filhos, Jorge e Paulo Affonso Franco, que já trabalhavam no Instituto Vacínico, assumiram a condução dos trabalhos da instituição, ficando a direção desta sob a responsabilidade de Paulo Franco.

O novo grupo de sanitaristas, que orientou as discussões que marcaram esse período, iniciou um rompimento com a estratégia política marcante na primeira década do século, que dava sustentação ao projeto do barão de Pedro Affonso. Esse projeto divergia das propostas construídas pelos discípulos de Oswaldo Cruz e assumidas pelo governo federal, com a criação do Departamento Nacional de Saúde Pública. Dessa vez, a divergência de propostas políticas para a organização dos serviços de saúde inviabilizou completamente a manutenção do Instituto Vacínico Municipal da forma como se constituía: uma instituição particular financiada pelo Estado.

Com a incorporação do Instituto Vacínico a Manguinhos, a vacina antivariólica no Distrito Federal passava a ter uma nova proposta, seguindo as orientações herdadas de Oswaldo Cruz e que ainda guiavam aquela instituição, unindo pesquisa e produção. A partir daí, ocorreram avanços no âmbito da pesquisa - que, em outros institutos, voltava-se para a tentativa de fabricar a vacina em ovo embrionado, buscando sua simplificação e purificação. Pela primeira vez na história do Instituto Vacínico da capital, seriam realizadas pesquisas e produzidos textos científicos. No Distrito 
Federal, seguindo o raciocínio de Moulin (1991, 1996), apenas nesse momento a ciência da vacinologia substituiria a vacinação.

É importante, no entanto, perceber que, mesmo lançando-se no campo da pesquisa e aproximando-se dos avanços observados em outros países, a vacina antivariólica continuou a ter o vitelo como lócus de sua produção. A adequação da técnica utilizada na fabricação da vacina antiamarílica para a produção da vacina antivariólica, utilizando ovo embrionado, não ocorreu em larga escala. O Instituto Oswaldo Cruz continuou a produzi-la prioritariamente em vitelos, traduzindo uma ambigüidade institucional pelo receio de romper com a tradição impressa à história da vacina. ${ }^{23}$

\section{Notas}

1 O conselheiro Nuno de Andrade teve, no período de fins do Império à Primeira República, lugar de destaque na categoria médica. Ocupou importantes funções públicas, tendo sido lente de Higiene na Faculdade de Medicina, inspetor de saúde do Porto, diretor do Hospício de Alienados, diretor-geral de Saúde Pública. Esteve, ainda, na presidência da Academia Nacional de Medicina.

2 Sobre a reforma urbana de Rodrigues Alves, destaca-se o estudo Pereira Passos: um Haussman tropical, realizado por Benchimol (1990).

3 Mesmo considerando esse momento como de incentivo à criação dos institutos de pesquisa, observam-se iniciativas de experimentação, principalmente na Faculdade de Medicina. Sobre o assunto, ver Edler, Ferreira e Santos (1990).

4 O Instituto Vacínico a que os críticos do projeto de Milanez se referem é o que Pedro Affonso vinha negociando com a prefeitura.

5 Durante todo o processo de discussão do projeto na Câmara, Mello Mattos foi acusado de estar apresentando uma proposta oficial, anunciando-a como proposição pessoal. Essas acusações partiam, principalmente, dos deputados Brício Filho, Teixeira Brandão e Sá Freire, membros da Comissão de Saúde Pública da Câmara (Anais da Câmara dos Deputados, jul. a dez. 1903).

6 As divergências entre Pedro Affonso e Oswaldo Cruz, na realidade, iniciaram-se no âmbito do Instituto Soroterápico Federal, quando Pedro Affonso ainda era seu diretor. A desavença entre eles fez com que Pedro Affonso solicitasse exoneração do cargo, assumindo Oswaldo Cruz a direção do Instituto. Sobre essa questão, ver Fernandes (1989) e Benchimol (1990).

7 Com relação à vacina antivariólica, os positivistas, pelo menos aqueles vinculados ao Apostolado, simbolizaram um movimento retrógrado, não visualizado por alguns estudiosos de outras áreas, e no qual essa filosofia/religião é ressaltada como responsável por avanços científicos.

8 Esse deputado será, ao longo de sua trajetória no Legislativo, um defensor da autonomia dos estados e municípios. 
9 Apesar de o nome oficial ser Instituto Vacínico, encontramos constantes referências a Instituto Vacinogênico. Este segundo, em geral, era utilizado para designar institutos onde somente se fabricava a vacina.

10 A referência à produção do imunoterápico antivariólico é expressa em um dos artigos da legislação de 1904, com o seguinte texto: “O Instituto (Soroterápico Federal) é obrigado a fornecer gratuitamente aos Estados e Municípios que os solicitarem os soros e as vacinas que preparar, não incluída no número destas a vacina antivariólica, que continuará, como até agora, a ser preparada, distribuída e fornecida aos Estados pelo Instituto Vacínico do Distrito Federal" (Decreto Legislativo n. 1.151 - 2o parágrafo - art. 795 - 05/01/1904).

11 Programa apresentado por Arthur Neiva ao conselheiro Rodrigues Alves como proposta para a reestruturação dos serviços de higiene, por ocasião do convite que recebeu para ocupar o cargo de diretor da Saúde Pública. Rodrigues Alves não assumiu a presidência, vítima do surto de gripe espanhola, e, conseqüentemente, Arthur Neiva não assumiu a diretoria.

12 Quanto à participação dos positivistas ante as questões da obrigatoriedade da vacina no Brasil, citamos o trabalho de Pôrto (1985).

13 Sobre o episódio da Revolta da Vacina existem trabalhos bastante significativos, como os de Pôrto (1985), Carvalho $(1984,1987)$ e Sevcenko (1984).

14 A maioria dos estudos elaborados sobre Oswaldo Cruz traz uma perspectiva pouco crítica sobre o papel desempenhado por ele, buscando simplesmente enaltecê-lo. Uma nova perspectiva de análise é oferecida no estudo desenvolvido por Nara Britto no âmbito da Casa de Oswaldo Cruz, que analisa criticamente o 'mito' Oswaldo Cruz (Britto, 1995).

15 Ainda no relatório de 1908, é apresentado um "Projeto de Reorganização Definitiva dos Serviços Sanitários a Cargo da União”. A elaboração desse plano foi justificada diante do fato de a Diretoria não ter ainda uma organização administrativa definida, permitindo ao Congresso prorrogar o orçamento destinado ao órgão, o que provocou uma situação de incerteza quanto ao funcionamento da Diretoria. A preocupação fundamental nesse projeto de 1908 centrava-se nos serviços de saúde dos portos e a profilaxia da febre amarela, vinculando a permanência de seus funcionários à erradicação da doença em todo o país. Mais uma vez, incluía-se como proposta a vacinação obrigatória, em conformidade com a legislação de 1904 (Diretoria Geral de Saúde Pública. Relatório, 1908).

16 O ofício de Oswaldo Cruz ao ministro faz parte do acervo da Casa de Oswaldo Cruz, em Minutas de Ofício (1912).

17 A proposta de Seidl tinha como base o projeto elaborado em 1908 por Oswaldo Cruz.

18 Esse texto é um documento extremamente rico e intitula-se "Golpe de vista retrospectivo sobre a varíola e a vacina no Rio de Janeiro” (1897-1917).

19 Programa apresentado por Arthur Neiva ao conselheiro Rodrigues Alves para a Reforma de Higiene no Brasil, citado anteriormente.

20 O diagnóstico de Belizário e Neiva baseou-se nas expedições realizadas no interior do país, que revelavam as condições de saúde na zona rural, afirmando que "o Brasil é um grande hospital”. Essa afirmativa teve repercussão nacional e internacional, servindo como um importante catalisador do processo de discussão sobre a 
questão sanitária em âmbito nacional. Essa questão é tratada em alguns trabalhos, como o desenvolvido por Labra (1985). Destacamos, ainda, o estudo desenvolvido na Casa de Oswaldo Cruz por Britto e Lima (1991), que analisam as discussões que envolvem a Liga Pró-Saneamento, principalmente por meio da Revista de Saúde.

${ }^{21}$ Acerca dessa polêmica no interior da Câmara, apontando para as articulações na negociação do projeto de centralização dos serviços, ver Hochman (1991).

22 O primeiro contrato estabelecido entre Pedro Affonso e a prefeitura do Rio de Janeiro, criando o Instituto Vacínico Municipal, previa uma indenização caso houvesse quebra de contrato por alguma das partes.

23 Uma recuperação histórica da transferência do Instituto Vacinogênico Federal para Manguinhos foi feita por Albino Taveira, em 1947, compondo uma coletânea organizada por ele, incorporada ao acervo da Casa de Oswaldo Cruz. 